Article

\title{
Biological Activities and ADMET-Related Properties of Novel Set of Cinnamanilides ${ }^{\dagger}$
}

\author{
Jiri Kos ${ }^{1}$, Andrzej Bak ${ }^{2} *{ }^{+}$, Violetta Kozik ${ }^{2}$, Timotej Jankech ${ }^{3}$, Tomas Strharsky ${ }^{1}$, \\ Aleksandra Swietlicka ${ }^{2}$, Hana Michnova ${ }^{1}$, Jan Hosek ${ }^{1}$ (D), Adam Smolinski ${ }^{4}{ }^{(\mathbb{D}}$, Michal Oravec ${ }^{5}$, \\ Ferdinand Devinsky ${ }^{6}\left(\mathbb{D}\right.$, Milan Hutta ${ }^{3}$ and Josef Jampilek ${ }^{3, *}(\mathbb{C}$ \\ 1 Regional Centre of Advanced Technologies and Materials, Faculty of Science, Palacky University, \\ Slechtitelu 27, 78371 Olomouc, Czech Republic; jiri.kos@upol.cz (J.K.); tomas.strharsky01@upol.cz (T.S.); \\ michnova.hana@gmail.com (H.M.); jan.hosek@upol.cz (J.H.) \\ 2 Department of Chemistry, University of Silesia, Szkolna 9, 40007 Katowice, Poland; \\ violetta.kozik@us.edu.pl (V.K.); aswietlicka@us.edu.pl (A.S.) \\ 3 Department of Analytical Chemistry, Faculty of Natural Sciences, Comenius University, Ilkovicova 6, \\ 84215 Bratislava, Slovakia; timotej.jankech@gmail.com (T.J.); milan.hutta@uniba.sk (M.H.) \\ 4 Central Mining Institute, Pl. Gwarkow 1, 40166 Katowice, Poland; smolin@gig.katowice.pl \\ 5 Global Change Research Institute CAS, Belidla 986/4a, 60300 Brno, Czech Republic; oravec.m@czechglobe.cz \\ 6 Faculty of Pharmacy, Comenius University, Odbojarov 10, 83232 Bratislava, Slovakia; \\ devinsky@fpharm.uniba.sk \\ * Correspondence: andrzej.bak@us.edu.pl (A.B.); josef.jampilek@gmail.com (J.J.) \\ + Preliminary results presented at the 23rd International Electronic Conference on Synthetic Organic \\ Chemistry, 15 November-15 December 2019; Available online: https://ecsoc-23.sciforum.net/.
}

Academic Editor: Julio A. A. Seijas Vázquez

Received: 24 August 2020; Accepted: 8 September 2020; Published: 9 September 2020

\begin{abstract}
A series of nineteen novel ring-substituted $N$-arylcinnamanilides was synthesized and characterized. All investigated compounds were tested against Staphylococcus aureus as the reference strain, two clinical isolates of methicillin-resistant S. aureus (MRSA), and Mycobacterium tuberculosis. (2E)- $N$-[3-Fluoro-4-(trifluoromethyl)phenyl]-3-phenylprop-2-enamide showed even better activity (minimum inhibitory concentration (MIC) 25.9 and $12.9 \mu \mathrm{M}$ ) against MRSA isolates than the commonly used ampicillin (MIC $45.8 \mu \mathrm{M}$ ). The screening of the cell viability was performed using THP1-Blue ${ }^{\mathrm{TM}}$ $\mathrm{NF}-\mathrm{kB}$ cells and, except for (2E)-N-(4-bromo-3-chlorophenyl)-3-phenylprop-2-enamide ( $\mathrm{IC}_{50} 6.5 \mu \mathrm{M}$ ), none of the discussed compounds showed any significant cytotoxic effect up to $20 \mu \mathrm{M}$. Moreover, all compounds were tested for their anti-inflammatory potential; several compounds attenuated the lipopolysaccharide-induced NF- $\mathrm{KB}$ activation and were more potent than the parental cinnamic acid. The lipophilicity values were specified experimentally as well. In addition, in silico approximation of the lipophilicity values was performed employing a set of free/commercial clogP estimators, corrected afterwards by the corresponding $\mathrm{pK}_{\mathrm{a}}$ calculated at physiological $\mathrm{pH}$ and subsequently cross-compared with the experimental parameters. The similarity-driven property space evaluation of structural analogs was carried out using the principal component analysis, Tanimoto metrics, and Kohonen mapping.
\end{abstract}

Keywords: cinnamamides; synthesis; antistaphylococcal activity; MTT assay; cytotoxicity; lipophilicity; PCA; IVE-PLS; quantitative structure-property relationships

\section{Introduction}

Inflammatory diseases of visceral organs, joints, bones, etc. can be based on an infectious or autoimmune basis, but the body always aims to eradicate noxious agents and restore tissue homeostasis [1]. A bacterial infection is often connected with severe inflammatory diseases such as 
bronchial asthma [2], gingivitis, periodontitis [3], systemic lupus erythematosus [4], and even with cancer [5]. Because the bacterial infection can trigger inflammation, which can cause subsequent damage of surrounding tissue [6], it seems advantageous to follow a multi-target approach in drug design and try to prepare molecules with dual antimicrobial and anti-inflammatory activity. Multi-target drug discovery represents an innovative approach of medicinal chemistry to overcome a crisis in drug design, reflected in the small number of newly approved drugs. This approach is based on the concepts of privileged scaffolds, polypharmacology, and multifactorial diseases [7-12]. Thus, multi-target drugs can be designed for the simultaneous treatment of, for example, autoimmune, inflammatory, and invasive diseases. From pharmacoeconomic and patients' comfort point of view, it seems favorable to treat both a cause and a consequence (bacterial infection and inflammation) simultaneously with one active substance.

Cinnamic acids are one of such privileged multi-target structures that occur naturally in all plants [13-15]. Cinnamic acids as well as hydroxy- and phenyl-substituted derivatives of cinnamic acids have been widely investigated due to their significant and varied biological effects including anti-inflammatory, antioxidant, hepatoprotective, antidiabetic, antidepressant/anxiolytic, antifungal, antibacterial, antiviral, and anticancer effects [16-24]. Derivatives of cinnamic acids are also used as agricultural fungicides [25]. Ring-substituted $N$-arylcinnamanilides were recently synthesized and tested for their antibacterial, antimycobacterial, anti-inflammatory potential and antifungal activity as well as for their activity related to the inhibition of photosynthetic electron transport (PET) in spinach (Spinacia oleracea L.) chloroplasts [26-28]. Since the $N$-phenylcinnamamide skeleton can be considered as a privileged scaffold providing multi-target agents, new di-, tri-, and tetra-halogenated $N$-arylcinnamanilides were prepared.

The biopharmaceutical profile of a compound is increasingly relevant for characterizing both the pharmacokinetic (ADMET) and pharmacodynamic aspects of drug-receptor/enzyme interactions $[29,30]$. The ADMET-friendly design of molecular in vivo permeability and cell bioaccumulation belongs to the field of the quantitative structure-property relationships (QSPR), where the physicochemical properties of a compound are the mathematical function of the chemical composition/constitution [31,32]. In this context, lipophilicity and its quantitative descriptor $(\log \mathrm{P})$ that often correlates well with the bioactivity of compounds indicate the differential partitioning of a neutral compound between two immiscible solvents ( $n$-octanol/water) under equilibrium conditions [33,34]. The existing experimental lipophilicity dataset is negligible $\left(3 \times 10^{4}\right)$ when compared to the enormous number of compounds under design; therefore, the reliable measure/estimation of lipophilicity is a valid requirement at the early stages of drug design [35]. Hence, an attractive alternative for lipophilicity estimation is in silico predictive protocols due to the additive-constitutive nature of the $\log P$ descriptor [36]. Regrettably, the comparative evaluation of implemented computational algorithms (linear or non-linear) revealed that the practical development of magic bullet (a global model for a diverse set of structural types) is dubious-the quality of lipophilicity estimation varies noticeably depending on the chemical type under consideration [37]. In order to eliminate a consequential uncertainty (over-/under-estimation) of clogP value, a possible vast range of in silico predictors should be engaged and compared with the available experimental data. As a matter of fact, early lipophilicity profiling (theoretical and/or empirical) might facilitate better decision-making in the hit $\rightarrow$ lead $\rightarrow$ seed $\rightarrow$ drug route and eradicate bad actors (false positive hits) at early stages of drug design/development according to the "fail fast, fail cheap" concept [38]. Due to the inaccuracy of clogP prediction, the potential exclusion of prospective drug molecules (false negative hits) at the preliminary step of drug discovery might happen using the Ro5 rule [39].

Depending on the target location and the track of administration, chemicals are exposed to $\mathrm{pH}$ variations in the physiological environment $(\mathrm{pH}=2-12)$. In the case of non-ionizable compounds, only neutral species exist; however, the majority of commercial pharmaceuticals contain an ionizable moiety-approximately $75 \%$ are basic, and $20 \%$ are acidic [40]. In fact, even partial ionization of a molecule results in the depletion of calculated/measured lipophilicity; therefore, the distribution 
coefficient $\log \mathrm{D}_{\mathrm{pH}}$ (the $\mathrm{pH}$ dependent version of $\log \mathrm{P}$ ) should be taken into consideration [41]. In fact, $\log \mathrm{D}_{\mathrm{pH}}$ potentially accumulates errors due to the $\log \mathrm{P}$ and dissociation constant $\left(\mathrm{pK}_{\mathrm{a}}\right)$ estimations according to the following formulas: $\log \mathrm{D}_{\mathrm{pH}}=\log \mathrm{P}-\log \left[1+10\left(\mathrm{pH}^{\mathrm{pK}} \mathrm{a}\right)\right]$ for acids and $\log \mathrm{D}_{\mathrm{pH}}=\log \mathrm{P}-\log \left[1+10^{\left(\mathrm{pK}_{\mathrm{a}}-\mathrm{pH}\right)}\right]$ for bases [42]. On the other hand, in many systems, ionic species enter the non-aqueous phase, and therefore a more rigorous approach would be appropriate, but this is beyond the scope of this paper.

In the presented study, a set of cinnamic acid anilide derivatives was synthesized, investigated for biological activity, and characterized by a series of experimental lipophilicity values generated using reversed-phase high-performance liquid (RP-HPLC) and reversed-phase thin-layer chromatography (RP-TLC). The similarity-related property space evaluation for the congeneric series of structurally-based analogs was carried out using the principal component analysis (PCA). Moreover, the in silico approximation of the lipophilic values for the ensemble of anilides 1-20 was performed employing a set of free/commercial clogP estimators, corrected afterwards by the corresponding $\mathrm{pK}_{\mathrm{a}}$ calculated at physiological $\mathrm{pH}$ and subsequently cross-compared with the experimental parameter. The mean values of the selected molecular descriptors that average over the chosen calculation methods were subsequently correlated with the $\log \mathrm{D}_{7.4}$ parameter, namely consensus clogP. Finally, the similarity-driven investigation using Tanimoto metrics and Kohonen mapping was conducted revealing some structural dissimilarities within the analyzed series of compounds.

\section{Results and Discussion}

\subsection{Synthesis and Biological Screening}

All compounds were synthesized from cinnamic acid in a microwave reactor: The carboxyl group was converted with phosphorus trichloride to acyl chloride, which then reacted with the appropriately substituted aniline to give the desired product (Scheme 1). The structures and biological activities are reported in Table 1, and empirically evaluated lipophilicity using RP-HPLC and RP-TLC are listed in Table 2.

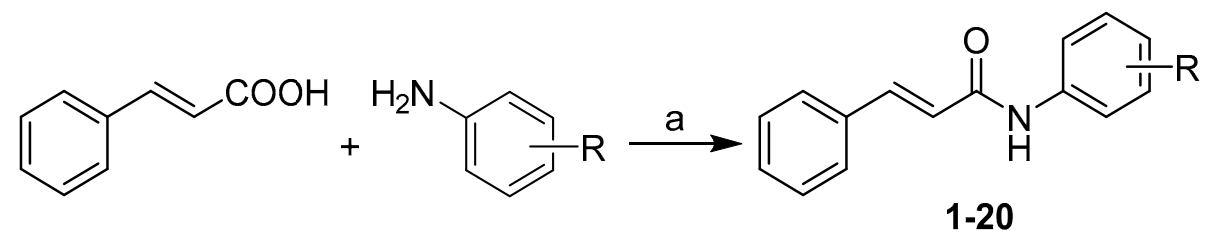

Scheme 1. Synthesis of ring-substituted (2E)-N-aryl-3-phenylprop-2-enamides 1-20. Reagents and conditions: (a) $\mathrm{PCl}_{3}$, chlorobenzene, $\mathrm{MW}(\max .500 \mathrm{~W}), 130{ }^{\circ} \mathrm{C}, 30 \mathrm{~min}[26,28]$.

\subsubsection{In Vitro Antimicrobial Evaluation}

The investigated compounds were tested on their antistaphylococcal activity against three clinical isolates of methicillin-resistant Staphylococcus aureus (MRSA) and S. aureus ATCC 29213 as the reference and quality control strain. Moreover, all compounds were tested against Mycobacterium tuberculosis ATCC 25177/H37Ra (see Table 1). As a matter of fact, all compounds showed very limited antimicrobial activity with the exception of compound $10\left(\mathrm{R}=3-\mathrm{F}-4-\mathrm{CF}_{3}\right)$ that revealed a significant effect against both S. aureus and MRSA isolates. It confirmed our previous findings, where compounds with $\mathrm{CF}_{3}$ moiety showed high antistaphylococcal and antitubercular activity [26,27]. Consequently, it was expected that other compounds with the $\mathrm{CF}_{3}$ motif, such as $13\left(\mathrm{R}=2-\mathrm{Br}-5-\mathrm{CF}_{3}\right)$ and $19\left(\mathrm{R}=2,6-\mathrm{Br}-4-\mathrm{CF}_{3}\right)$ or compound $6(\mathrm{R}=3,4,5-\mathrm{Cl})$, derived from 3,5-Cl (highly effective against $M$. tuberculosis) should have similar activity [26]. Unfortunately, only molecule 10 turned out to be active. Because the minimum inhibitory concentrations (MICs) of compound $\mathbf{1 0}$ are the same against both S. aureus and MRSA isolates (25.9 and $12.9 \mu \mathrm{M})$, it can be speculated concerning the specific activity against Staphylococcus sp. In addition, 
all compounds were verified against the reference strain Enterococcus faecalis ATCC 29212 and three vanA-carrying vancomycin-resistant $E$. faecalis (VRE) isolates; however no activity was recorded.

It is should be emphasized that besides MIC values, minimum bactericidal concentrations (MBCs) were also determined for compound 10. All MBC values were equal to the MIC values, indicating that compound $\mathbf{1 0}$ showed not only bacteriostatic but bactericidal activity. In fact, a tested compound is classified as bactericidal if the ratio of its MBC/MIC values is $\leq 4$ [43].

Finally, 3-(4,5-dimethylthiazol-2-yl)-2,5-diphenyltetrazolium bromide (MTT) assay of effective antistaphylococcal compound $\mathbf{1 0}$ was conducted as well. The MTT test is employed to assess cell growth by measuring respiration. The MTT measured viability of bacterial cells less than 70\% [44] after the exposure to the MIC values of tested compound is considered as a positive result of this assay, because this low level of cell viability indicates the inhibition of cell growth by the inhibition of respiration [45]. It can be concluded that compound $\mathbf{1 0}$ showed a significant decrease in viability to $13.4 \pm 0.1 \%$, which is far below the limit of $70 \%$ viability of $S$. aureus ATCC 29213 at the tested concentration equal to MIC (i.e., $25.9 \mu \mathrm{M}(8 \mu \mathrm{g} / \mathrm{mL})$.

Table 1. Structure of ring-substituted (2E)- $N$-aryl-3-phenylprop-2-enamides 1-20, in vitro antiStaphylococcus activities' minimum inhibitory concentration (MIC; $\mu \mathrm{M})$ in comparison with standard ampicillin (AMP), in vitro antitubercular activity MIC $(\mu \mathrm{M})$ in comparison with standard isoniazid (INH), and their influence on viability of THP1-Blue ${ }^{\mathrm{TM}} \mathrm{NF}-\mathrm{kB}$ cell line $\left(\mathrm{IC}_{50}(\mu \mathrm{M}) \pm \mathrm{SEM}, \mathrm{n}=6\right)$.

\begin{tabular}{|c|c|c|c|c|c|c|}
\hline \multirow{2}{*}{ Comp. } & \multirow{2}{*}{$\mathbf{R}$} & \multicolumn{4}{|c|}{$\operatorname{MIC}(\mu \mathrm{M})$} & \multirow{2}{*}{$\begin{array}{c}\text { Tox } \mathrm{IC}_{50} \\
(\mu \mathrm{M}) \pm \mathrm{SEM}\end{array}$} \\
\hline & & SA & MRSA 63718 & MRSA SA 630 & Mtb & \\
\hline $1 *$ & $\mathrm{H}$ & $>1146$ & $>1146$ & $>1146$ & 286 & $>20$ \\
\hline 2 & $2,4,6-F$ & $>924$ & $>924$ & $>924$ & $>462$ & $>20$ \\
\hline 3 & $3,4,5-F$ & 462 & $>924$ & $>924$ & $>462$ & $>20$ \\
\hline 4 & $2,4-\mathrm{Cl}$ & $>880$ & $>880$ & $>880$ & $>440$ & $>20$ \\
\hline 5 & $2,4,5-\mathrm{Cl}$ & $>790$ & $>790$ & $>790$ & $>395$ & $>20$ \\
\hline 6 & $3,4,5-\mathrm{Cl}$ & $>790$ & $>790$ & $>790$ & $>395$ & $>20$ \\
\hline 7 & $2,4-\mathrm{Br}$ & $>677$ & $>677$ & $>677$ & $>339$ & $>20$ \\
\hline 8 & $2-\mathrm{F}-5-\mathrm{Cl}$ & 931 & $>931$ & $>931$ & $>465$ & $>20$ \\
\hline 9 & 3-F-4-Br & $>805$ & $>805$ & 805 & $>403$ & $>20$ \\
\hline 10 & 3-F-4- $\mathrm{CF}_{3}$ & 25.9 & 25.9 & 12.9 & $>414$ & $>20$ \\
\hline 11 & $3-\mathrm{Cl}-4-\mathrm{Br}$ & $>766$ & 192 & 192 & $>383$ & $6.5 \pm 1.0$ \\
\hline 12 & 2-Br-4-Cl & $>766$ & $>766$ & $>766$ & $>383$ & $>20$ \\
\hline 13 & $2-\mathrm{Br}-5-\mathrm{CF}_{3}$ & $>696$ & $>696$ & $>696$ & $>348$ & $>20$ \\
\hline 14 & $2-\mathrm{CF}_{3}-4-\mathrm{F}$ & $>828$ & $>828$ & $>828$ & $>414$ & $>20$ \\
\hline 15 & $2-\mathrm{CF}_{3}-4-\mathrm{Cl}$ & $>788$ & $>788$ & $>788$ & $>394$ & $>20$ \\
\hline 16 & $2-\mathrm{CF}_{3}-4-\mathrm{Br}$ & $>696$ & $>696$ & $>696$ & $>348$ & $>20$ \\
\hline 17 & $2-\mathrm{CF}_{3}-4-\mathrm{NO}_{2}$ & $>762$ & $>762$ & $>762$ & $>381$ & $>20$ \\
\hline 18 & $3-\mathrm{CF}_{3}-4-\mathrm{NO}_{2}$ & $>762$ & $>762$ & $>762$ & $>381$ & $>20$ \\
\hline 19 & $2,6-\mathrm{Br}-4-\mathrm{CF}_{3}$ & $>574$ & $>574$ & $>574$ & $>287$ & $>20$ \\
\hline 20 & $2,6-\mathrm{Br}-3-\mathrm{Cl}-4-\mathrm{F}$ & $>595$ & $>595$ & $>595$ & $>298$ & $>20$ \\
\hline AMP & - & 5.72 & 45.8 & 45.8 & - & - \\
\hline INH & - & - & - & - & 36.6 & - \\
\hline
\end{tabular}

* compound was described in reference [26]; SA = Staphylococcus aureus ATCC 29213; MRSA = clinical isolates of methicillin-resistant S. aureus 63,718 and SA 630 (National Institute of Public Health, Prague, Czech Republic); $\mathrm{Mtb}=$ Mycobacterium tuberculosis H37Ra. 
Table 2. Experimentally found lipophilicity determined using HPLC and TLC approaches for $\mathrm{N}$-arylcinnamanilides 1-20.

\begin{tabular}{|c|c|c|c|c|c|c|c|}
\hline \multirow{2}{*}{ Comp. } & \multirow{2}{*}{$\mathbf{R}$} & \multicolumn{3}{|c|}{ RP-HPLC } & \multicolumn{3}{|c|}{ RP-TLC } \\
\hline & & $\operatorname{Logk}^{a}$ & $\log \mathrm{D}^{b}$ & $\log \mathrm{D}^{\mathrm{c}}$ & $R_{M}{ }^{d}$ & $\mathbf{R}_{\mathbf{M}}{ }^{\mathbf{e}}$ & $R_{M}{ }^{f}$ \\
\hline 1 & $\mathrm{H}$ & 0.0270 & 0.1251 & 0.1090 & -0.5087 & 0.2848 & 0.4038 \\
\hline 2 & $2,4,6-F$ & -0.0831 & 0.0260 & 0.0107 & -0.6536 & 0.1218 & 0.1951 \\
\hline 3 & $3,4,5-\mathrm{F}$ & 0.4893 & 0.5495 & 0.5274 & -0.4206 & 0.6074 & 0.5495 \\
\hline 4 & $2,4-\mathrm{Cl}$ & 0.5278 & 0.5885 & 0.5685 & -0.3933 & 0.6546 & 0.5495 \\
\hline 5 & $2,4,5-\mathrm{Cl}$ & 0.8373 & 0.8879 & 0.8647 & -0.2497 & 0.9695 & 0.9832 \\
\hline 6 & $3,4,5-\mathrm{Cl}$ & 0.9671 & 1.0104 & 0.9897 & -0.1870 & 1.0852 & 1.1306 \\
\hline 7 & $2,4-\mathrm{Br}$ & 0.6152 & 0.6704 & 0.6518 & -0.3098 & 0.7331 & 0.7295 \\
\hline 8 & 2-F-5-Cl & 0.3692 & 0.4334 & 0.4154 & -0.4711 & 0.5411 & 0.5495 \\
\hline 9 & $3-\mathrm{F}-4-\mathrm{Br}$ & 0.5025 & 0.5597 & 0.5408 & -0.4081 & 0.6797 & 0.6895 \\
\hline 10 & $3-\mathrm{F}-4-\mathrm{CF}_{3}$ & 0.5789 & 0.6327 & 0.6095 & -0.5032 & 0.7923 & 0.5960 \\
\hline 11 & $3-\mathrm{Cl}-4-\mathrm{Br}$ & 0.6611 & 0.7126 & 0.6912 & -0.3376 & 0.8388 & 0.8181 \\
\hline 12 & $2-\mathrm{Br}-4-\mathrm{Cl}$ & 0.5476 & 0.6064 & 0.5860 & -0.4072 & 0.6553 & 0.6484 \\
\hline 13 & $2-\mathrm{Br}-5-\mathrm{CF}_{3}$ & 0.5561 & 0.6157 & 0.5936 & -0.4325 & 0.7194 & 0.5619 \\
\hline 14 & $2-\mathrm{CF}_{3}-4-\mathrm{F}$ & 0.1607 & 0.2426 & 0.2220 & -0.6797 & 0.3011 & 0.1330 \\
\hline 15 & $2-\mathrm{CF}_{3}-4-\mathrm{Cl}$ & 0.4113 & 0.4741 & 0.454 & -0.6102 & 0.5305 & 0.3219 \\
\hline 16 & $2-\mathrm{CF}_{3}-4-\mathrm{Br}$ & 0.4683 & 0.5316 & 0.5105 & -0.5624 & 0.5730 & 0.4273 \\
\hline 17 & $2-\mathrm{CF}_{3}-4-\mathrm{NO}_{2}$ & 0.3794 & 0.4431 & 0.3989 & -0.5633 & 0.4998 & 0.4311 \\
\hline 18 & $3-\mathrm{CF}_{3}-4-\mathrm{NO}_{2}$ & 0.5004 & 0.5571 & 0.5098 & -0.4804 & 0.6927 & 0.6160 \\
\hline 19 & $2,6-\mathrm{Br}-4-\mathrm{CF}_{3}$ & 0.4321 & 0.4941 & 0.4731 & -0.5206 & 0.5301 & 0.3733 \\
\hline 20 & 2,6-Br-3-Cl-4-F & 0.3139 & 0.3922 & 0.3699 & -0.5541 & 0.4320 & 0.4138 \\
\hline
\end{tabular}

a $72: 28 \mathrm{MeOH}: \mathrm{H}_{2} \mathrm{O} ;{ }^{\mathrm{b}} 72: 28 \mathrm{MeOH}: \mathrm{NaOAc}$ buffer (pH 7.4), ${ }^{\mathrm{c}} 72: 28 \mathrm{MeOH}$ : NaOAc buffer (pH 6.5), ${ }^{\mathrm{d}} 100 \% \mathrm{MeOH}$,

e $72: 28 \mathrm{MeOH}: \mathrm{H}_{2} \mathrm{O},{ }^{\mathrm{f}}$ 72:28 MeOH: NaOAc buffer (pH 7.4).

\subsubsection{In Vitro Cell Viability and Anti-Inflammatory Potential}

In vitro cell viability of all the compounds was estimated using the human THP1-Blue ${ }^{\mathrm{TM}}$ NF- $\mathrm{KB}$ cell line. Almost all tested compounds showed insignificant cytotoxic effect $\left(\mathrm{IC}_{50}>20 \mu \mathrm{M}\right)$ (Table 1) with exception of molecule $11\left(\mathrm{R}=3-\mathrm{Cl}-4-\mathrm{Br}, \mathrm{IC}_{50}=6.5 \pm 1.0 \mu \mathrm{M}\right)$. It seems that the disubstitution of $\mathrm{C}_{(3,4)^{\prime}}$ by highly lipophilic and electron-withdrawing moieties (combination of chlorine and bromine) is critical for the toxic effect of the analyzed series of compounds.

With respect to the used THP1-Blue ${ }^{\mathrm{TM}} \mathrm{NF}-\mathrm{KB}$ cells, the anti-inflammatory potential of compounds was evaluated in order to modulate the activity of the pro-inflammatory transcription nuclear factor (NF)- $\mathrm{KB}$ (see Figure 1). After lipopolysaccharide (LPS) stimulation, compounds $14\left(\mathrm{R}=2-\mathrm{CF}_{3}-4-\mathrm{F}\right)$, $18\left(\mathrm{R}=3-\mathrm{CF}_{3}-4-\mathrm{NO}_{2}\right)$, and $20(\mathrm{R}=2,6-\mathrm{Br}-3-\mathrm{Cl}-4-\mathrm{F})$ showed the highest attenuation of the activity of this transcription factor within the studied set of compounds; however, the decrease was approximately $9 \%$, which was lower compared to the previously verified cinnamides [28]. On the other hand, the half concentration of tested compounds was used in the study. As a matter of fact, compounds 2 $(\mathrm{R}=2,4,6-\mathrm{F}), 4(\mathrm{R}=2,4-\mathrm{Cl}), \mathbf{5}(\mathrm{R}=2,4,5-\mathrm{Cl})$, and $10\left(\mathrm{R}=3-\mathrm{F}-4-\mathrm{CF}_{3}\right)$ significantly increased the activity of NF- $\mathrm{kB}$ by $10-15 \%$, respectively. It seems that the position and type of substituents on phenyl ring is important for tuning pro-/anti-inflammatory potential of cinnamic acid anilides, which confirms similar observations in our previous study, where the substitution of ortho and meta positions of the anilide ring by rather lipophilic and bulky moieties was preferred for the anti-inflammatory potential [28].

Surprisingly, the insignificant anti-inflammatory potential of compound $13\left(\mathrm{R}=2-\mathrm{Br}-5-\mathrm{CF}_{3}\right)$ is disappointing, because its chlorinated analogue showed promising activity [28]. It can be hypothesized that the investigated $N$-arylcinnamanilides may have a different mode of action, which may be the nuclear translocation of NF- $\mathrm{KB}$ inhibition, or affecting its binding to DNA, or acting by epigenetic regulation, while combinations of these effects are not excluded. 


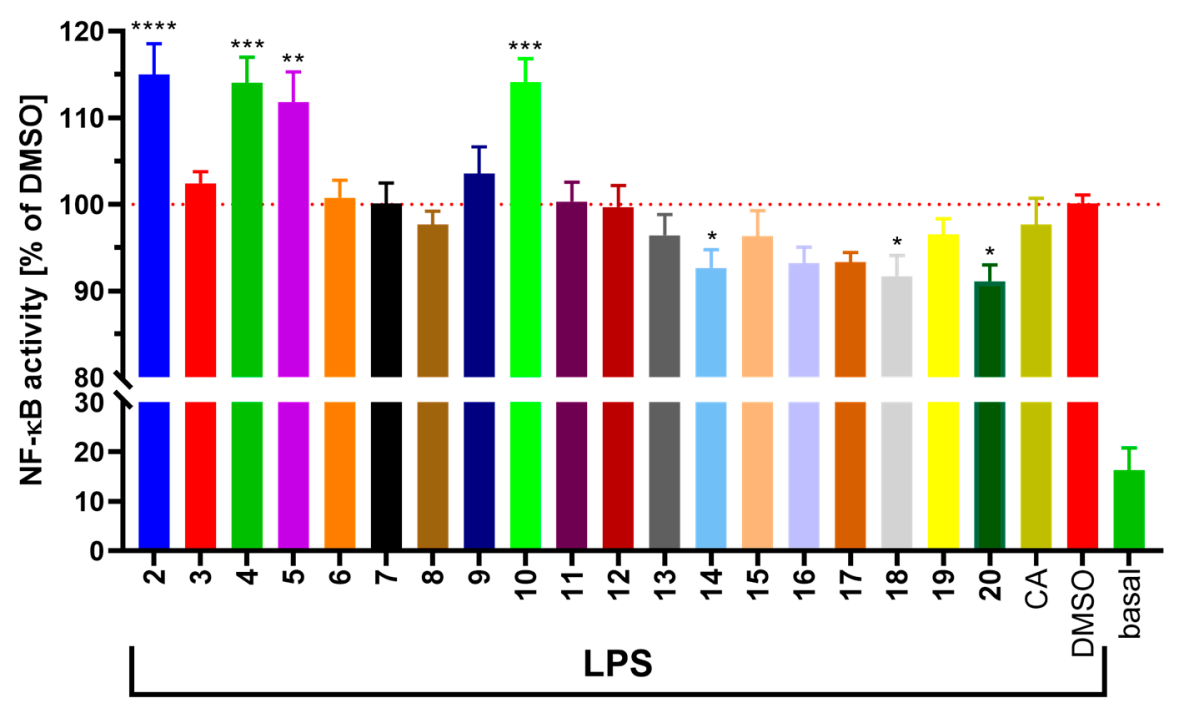

Figure 1. Effect of tested compounds on activity of transcription factor NF- $\kappa B$. THP1-Blue ${ }^{\mathrm{TM}}$ NF- $\kappa \mathrm{B}$ cells were pretreated by compounds $(1 \mu \mathrm{M})$ dissolved in dimethyl sulfoxide (DMSO) for $1 \mathrm{~h}$. Then, lipopolysaccharide (LPS) $1 \mu \mathrm{g} / \mathrm{mL}$ was added to trigger the NF- $\kappa B$ activation. The activity of NF- $\kappa B$ was measured $24 \mathrm{~h}$ after LPS stimulation using QuantiBlue ${ }^{\mathrm{TM}}$ assay. The graph represents mean \pm SEM $(n=9)$. The red dotted line shows the value of the DMSO-only treated group. Groups were compared with the help of the one-way ANOVA test followed by Fisher's LSD multiple comparison test. * indicates statistical significance $(p<0.05)$ to DMSO group; ${ }^{* *}$ indicates statistical significance $(p<0.01)$ to DMSO group; ${ }^{* * *}$ indicates statistical significance $(p<0.001)$ to DMSO group; ${ }^{* * * *}$ indicates statistical significance $(p<0.0001)$ to DMSO group. CA—cinnamic acid.

\subsection{Similarity-Driven Property Evaluation}

The similarity-guided assessment of the property profile for the group of structurally alike compounds was conducted for the congeneric set of cinnamic acid anilide analogues. The a priori calculation of molecular descriptors, regarded as the result of mathematical transformation of chemical information encoded within a symbolic representation of a molecule is crucial for the compound's bioavailability and hence critical for the prospective drug candidate properties. The gold standard of ADMET-tailored property approximation is the generation of statistically robust models, where a property is a function of the chemical structure, that are capable of making accurate quantitative predictions, including those of molecular binding affinity, metabolic/pharmacokinetic/ pharmacodynamics fate, or environmental ecotoxicology. The molecular descriptors are essentially estimated based on the molecular structure as intuitive roadmaps even before the synthesis of the molecule has been rationalized. In fact, the majority of topological descriptors is highly intercorrelated; therefore, it is necessary to employ the linear (e.g., PCA) or non-linear (e.g., neural network) techniques to reduce the data dimensionality and illustrate the object similarity in the orthogonal basis using the pair-wise descriptor-based structural resemblance/relatedness measure of the intermolecular resemblance between two objects (e.g., Euclidean metric) [46]. Initially, the principal component analysis (PCA) was performed on the pool of 2567 descriptors calculated using Dragon 6.0 program, where constant and nearly constant variables (standard deviation $<10^{-4}$ ) were a priori eradicated. Subsequently, the multidimensional matrix was generated $\left(X_{20 \times 2567}\right)$ with rows and columns representing variables (descriptors) and objects (molecules), respectively. The PCA procedure was employed on the centered and standardized dataset. The compression efficacy of the PCA method is strictly related to the number of uncorrelated variables; therefore, the high percentage of total variance explained by the first three principal components (PC1 + PC2 + PC3 $=77.98 \%)$ implies, that descriptors are highly inter-correlated. In fact, first two PCs described $71.44 \%$ of the total variance; hence, the chosen properties were projected on the plane specified by the PC1 versus PC2-predicted scores as illustrated in Figure 2a. 

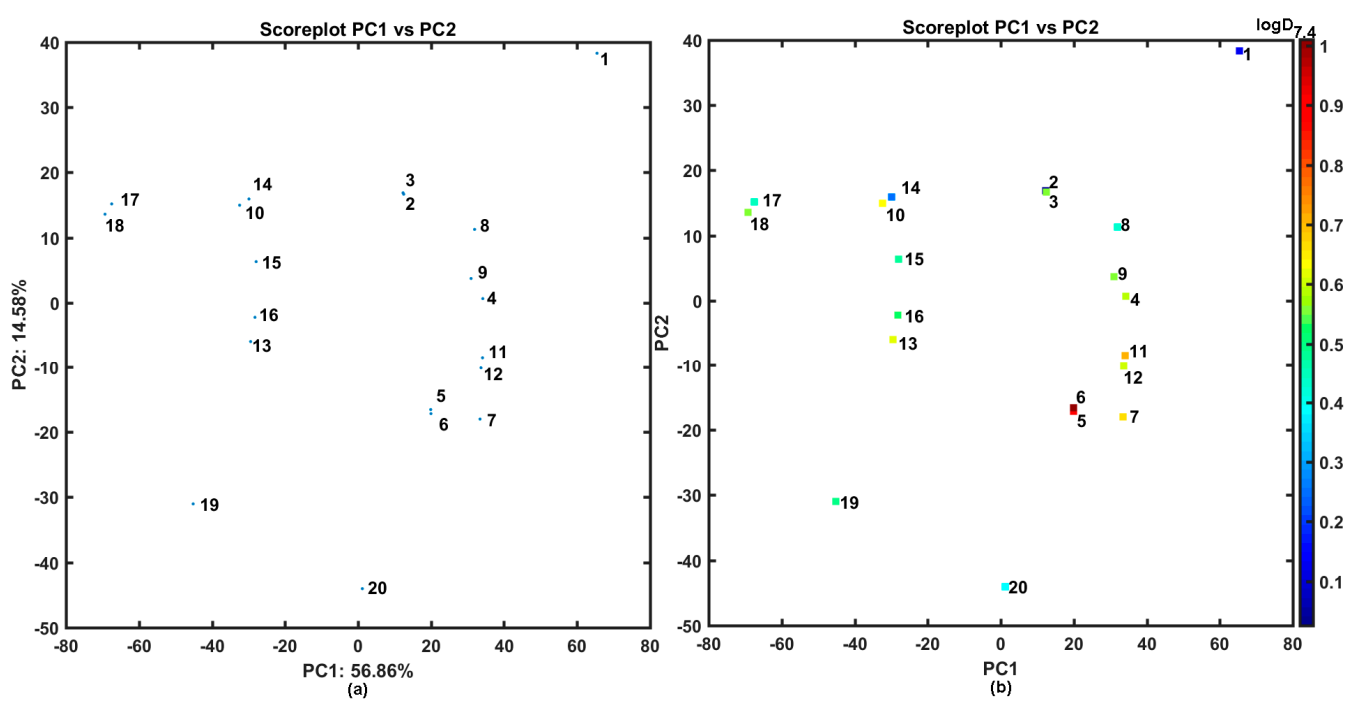

Figure 2. Projection of cinnamic acid anilides 1-20 on plane defined by first vs. second principal components for Dragon descriptors (a) with experimental $\log \mathrm{D}_{7.4}(\mathbf{b})$. Colors code numerical values of $\log \mathrm{D}$ at $\mathrm{pH}=7.4$.

Basically, two subfamilies can be formed along the positive and negative values of PC1 for the analyzed 1-20 anilides that share a common chemotype based on styrene-containing motif, peptide-like linker, and phenyl R-substituted ring. The first group (PC1 $>0)$ contains $\mathrm{di} /$ tri/tetra-halogenated analogues (objects 2-9, 11, 12, 20), while the second one $(\mathrm{PC1}<0)$ is composed of mono-trifluoromethyl-based molecules (objects 10, 13-19). Interestingly, compounds 19 and 20 are located distinctly along the second principal component (PC2 <-30). Not surprisingly, unsubstituted (only hydrogenated) molecule $\mathbf{1}$ is separated from the remaining ones. The similarity-driven analysis of the empirical lipophilicity at the physiological $\mathrm{pH}=7.4$ is illustrated on the PC1 vs. PC2 plane. In fact, the most lipophilic molecules 5-7 and $\mathbf{1 1}$ are grouped together as shown in Figure $\mathbf{2 b}$.

On the whole, the vast number of the investigated anilides abide the Lipinski's Rule of Five (Ro5), where the ADMET-friendly properties are confined by the liminal values imposed on the specific molecular descriptors ( $\mathrm{MW} \leq 500, \mathrm{HBD} \leq 5, \mathrm{HBA} \leq 10, \operatorname{cog} \mathrm{P} \leq 5$ ). Interestingly, the Ro5 violation observed for molecules depicted in Figure $3 \mathrm{a}$ is strictly related with the calculated lipophilicity values $(\log P>5)$. Despite the drug-like property space is still a questionable concept, because a good drug-like score does not make a molecule a drug and vice versa, the Ro5 rule might be handy in differentiating a prospective drug from a non-drug molecule [47]. Moreover, almost all tested compounds showed very low cytotoxic effect $\left(\mathrm{IC}_{50}>20 \mu \mathrm{M}\right)$ as presented in Figure $3 \mathrm{~b}$ and Table 1 . Compound $11\left(\mathrm{IC}_{50}=6.5 \mu \mathrm{M}\right)$ is the visible exception, which is also annotated with Ro5 violation. As mentioned above, it seems that the $\mathrm{C}_{(3,4)}$ ' disubstitution by chlorine and bromine is critical for the viability of cells unlike the disubstitution of $\mathrm{C}_{(2,4)^{\prime}}$ positions. Since the lipophilicity is regarded as a meaningful property in the context of pharmacokinetic and pharmacodynamic drug-receptor interactions, the lipophilic profiles of the analyzed anilide analogues were thoroughly investigated.

From the drug hunter perspective, the justifiable precariousness of the validity of lipophilicity estimation can arise, using a variety of theoretical approaches, because some methods for the theoretical calculation of lipophilicity might be more or less suitable for specific/heterogeneous series of compounds. In other words, the non-trivial question arises how to single out the best-suited method or combination of methods for $\operatorname{cog} P$ estimation of new compounds. It is known that a jack of all trades is a master of none; therefore, it seems advisable not to rely solely on one clogP estimator, but rather a combination of methods should be engaged with subsequent comparison of the results with the experimental data. Hence, a consensus procedure for $\operatorname{cog} P$ prediction was previously proposed based on a consensus methodology that was adopted from the structure-based studies, where many docking programs and scoring functions can be employed [48-50]. Thus, in silico approximation of the lipophilic values for 
the ensemble of anilides 1-20 was performed employing a set of free/commercial clogP estimators such as clogPS, Molinspirations, OSIRIS, HyperChem 7.0, Sybyl-X, MarvinSketch 15, ACD/ChemSketch 2015, Dragon 6.0, Kowwin, XlogP3, ChemDraw, and ACD/Percepta (Table S1 in Supplementary Materials). Moreover, the deduced $\operatorname{clog} \mathrm{P}$ values were corrected afterwards by the corresponding $\mathrm{pK}_{\mathrm{a}}$ calculated at specific $\mathrm{pH}$ using ACD/Percepta/pKa Classic module (Table S2 in Supplementary Materials). The obtained $\operatorname{cog} \mathrm{D}_{\mathrm{pH}}$ does not differ significantly from clogP specified by distinct in silico principles, because the investigated molecules do not contain an ionizable moiety. Furthermore, the $\operatorname{cog} \mathrm{D}_{7.4}$ findings were inter-correlated with each other and cross-compared with the empirical $\log \mathrm{D}_{7.4}$ values as illustrated by the triangular matrix of linear correlations parameters in Figure 4 .
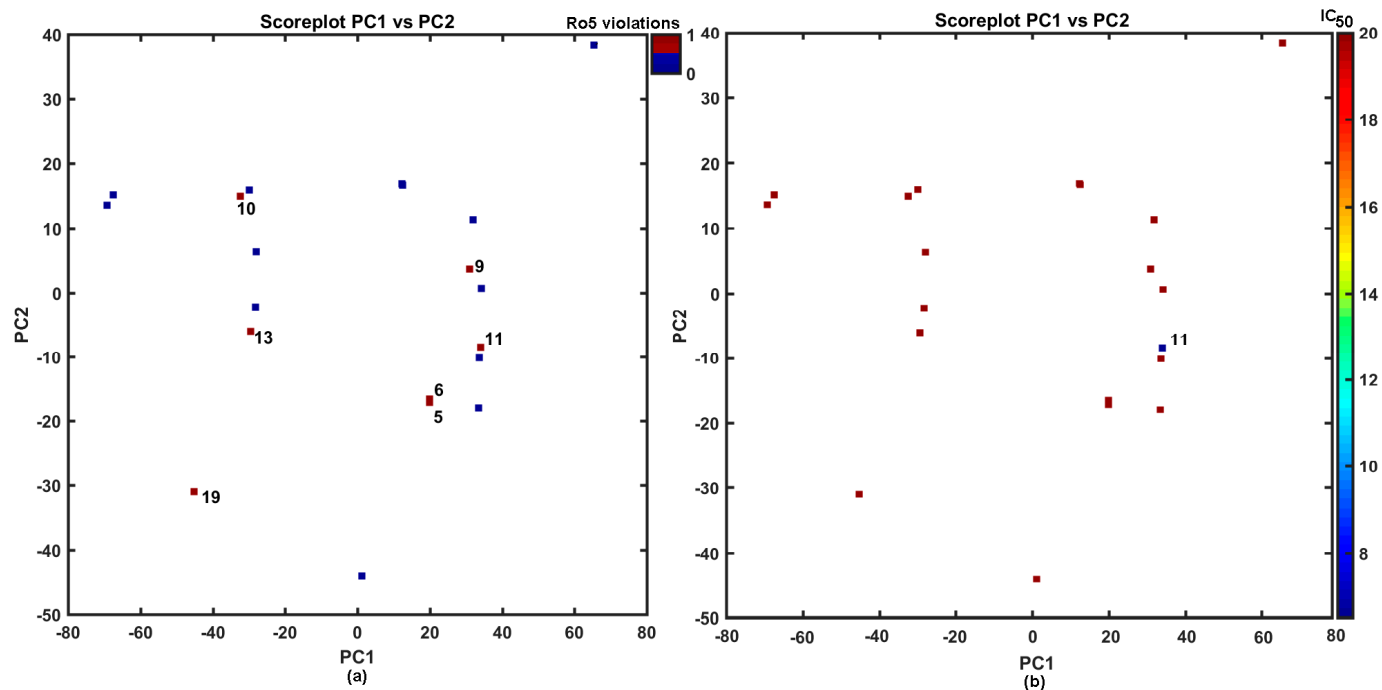

Figure 3. Projection of cinnamic acid anilides 1-20 on a plane defined by first vs. second principal components for Dragon descriptors with Ro5 rule violations (a) and cytotoxic effect $\mathrm{IC}_{50}(\mathbf{b})$. Colors code numerical values of Ro5 violations and $\mathrm{IC}_{50}$.

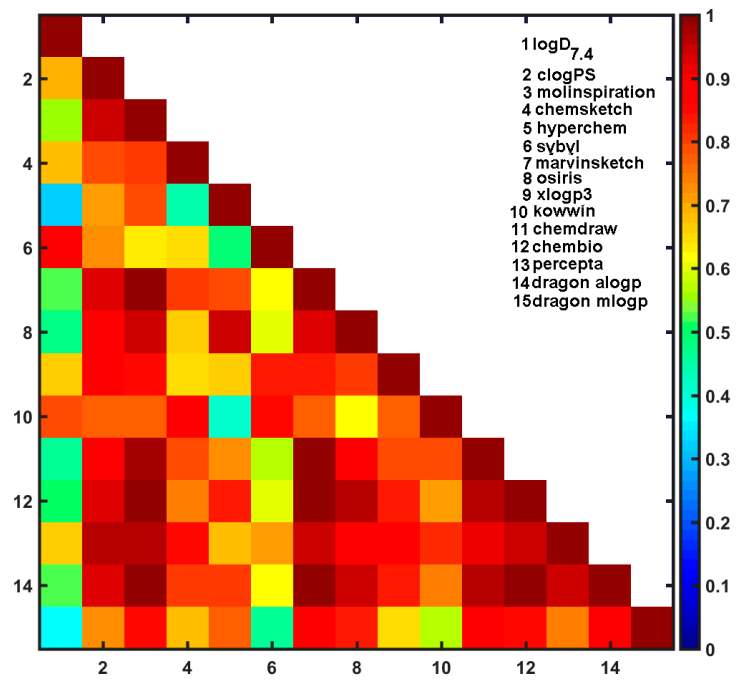

Figure 4. Matrix of correlation coefficients of linear relationships between experimental and calculated $\log \mathrm{D}_{7.4}$ lipophilicity specified using different programs.

In fact, relatively good correlation $(\mathrm{r}>0.65)$ between experimental $\log \mathrm{D}_{7.4}$ and model-predicted $\operatorname{cog} \mathrm{D}_{7.4}$ values was recorded for clogPS, ChemSketch, Sybyl, XlogP3, and Kowwin estimators. On the other hand, rather poor correlation $(\mathrm{r} \leq 0.4)$ was revealed for data provided by HyperChem and Dragon predictors (see Figure 4). The noticeable variations in $\log \mathrm{D}$ estimation at given $\mathrm{pH}$ probably resulted from different computational algorithms (atom/fragment- or descriptor-based) implemented in the 
software and/or training data engaged at the training stage. Obviously, prediction of the individual lipophilic contribution of each group/atom (sometimes augmented by the structural correction factors) is as good as the modeling data used at the training stage of model generation [51]. In other words, the poorer performance of some predictors focuses on issues arising from the lipophilicity estimation for the in house collection of molecules with structural features uncovered by chemical classes of compounds in the training subset-a wide range of chemical space is still not covered [52]. Luckily, usually a few empirically measured values are sufficient to produce reliable lipophilicity estimation for structurally related series of molecules. Hence, the integrated clog $\mathrm{D}_{7.4}$ matrix $\left(\mathrm{X}_{20 \times 14}\right)$ and empirical $\log \mathrm{D}_{7.4}$ were subjected to the backward elimination PLS-based procedure (IVE) indicating Sybyl-X, XlogP3, Kowwin, ACD/Percepta, and HyperChem as valid contributors to the final QSPR model $\left(q_{c v}^{2}=0.72, q_{\text {test }}^{2}=0.9, A_{o p t}=7\right)$. The mean and median values of the selected estimators that averaged over the chosen $\log \mathrm{D}_{7.4}$ values were subsequently correlated with the experimental parameter with correlation coefficient 0.65 , because not only the best inter-correlated clog $\mathrm{D}_{7.4}$ values were specified in the consensus clogP approach.

The similarity tenet in the chemical space (CS) is the core of many SAR-driven procedures, where structurally alike molecules are expected to display similar physicochemical and/or pharmacological properties [53]. Conceptually, a numerical measure of molecular diversity between two objects can be quantitatively expressed by a bit-string representation (sometimes augmented with the scaling coefficients) in the function of (un-)common features. Unarguably, it is still a powerful concept despite some obvious oversimplification of the similarity quantification (e.g., some similarity scores exhibit size-dependent behavior) [54]. The pairwise relatedness between descriptor-guided structures can be numerically evaluated by a variety of relative distance metrics (e.g., Hamming or Euclidean measures) or absolute comparison using Tanimoto coefficient calculated for molecular fingerprints (e.g., OpenBabel) [55]. The distribution of Tanimoto coefficients for the ensemble of investigated anilides 1-20 is illustrated in Figure 5a, where the highest frequency was recorded in the pretty wide range of $0.55<\mathrm{T}<0.75$. The detailed inspection of the symmetric Tanimoto coefficient matrix $\left(\mathrm{T}_{20 \times 20}\right)$ in Figure 5b reveals the structural dissimilarities of nitro-substituted isomers (compounds $\mathbf{1 7}$ and 18) as compared with the remaining ones that confirms our previous PCA $(\mathrm{PC} 1<-60)$ findings (see Figure 2a). Interestingly, mono-bromo/chloro- substituted isomers (molecules 11 and 12) indicate the structural similarity to di-/tri-bromo/chloro- substituted positional isomers (compounds 4-9) as was also shown in Figure 2a $(\mathrm{PC} 1>20)$. Unfortunately, the similarity investigation did not provide valuable hints that could explain the noticeable variations in the toxic effect exerted by molecule $\mathbf{1 1}$ (see Figure $3 b$ ) and the remaining ones.
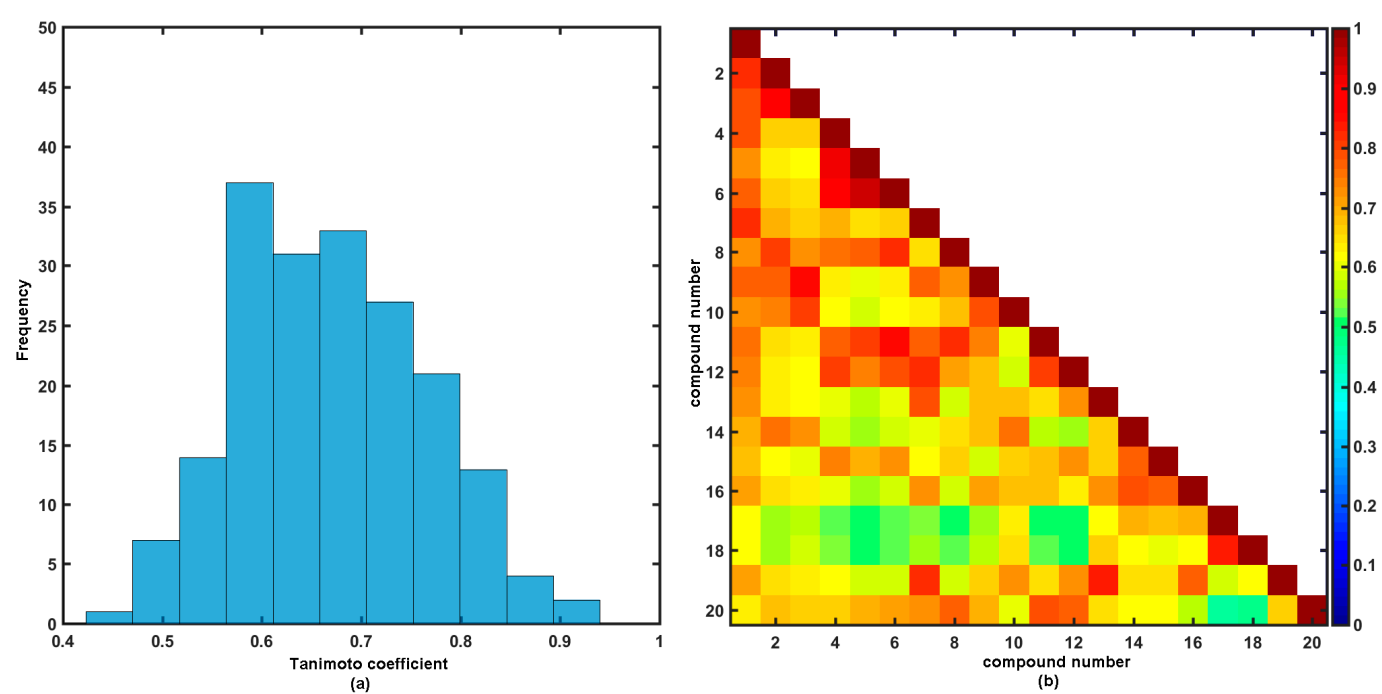

Figure 5. Distribution of Tanimoto coefficients (a) and triangular matrix of Tanimoto coefficients (b) for 1-20 anilides. 


\section{Comparative Molecular Shape Analysis}

The molecular shape analysis of the cinnamic acid anilides was performed, because the molecular electrostatics and lipophilicity are two important properties used in the rational drug design. Firstly, the 11-ordered atom trial alignment of the most active molecule $\mathbf{1 0}$ (active analogue approach, AAA) was applied to cover the entire bonding topology in the maximal common structure (MCS) in the FIT method as illustrated in Figure 6.

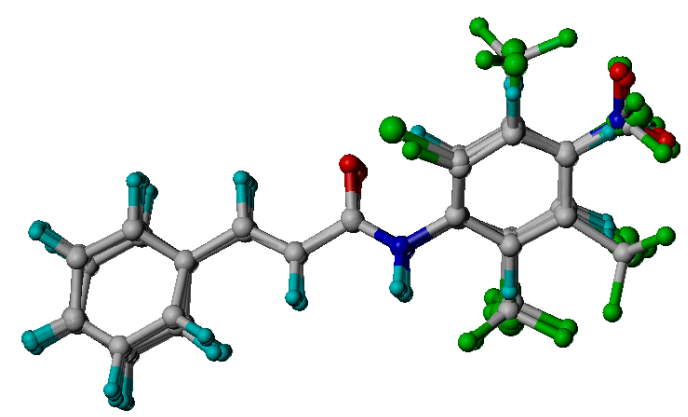

Figure 6. Superimposition of 1-20 anilides according to AAA hypothesis.

Secondly, the molecular electrostatic potentials (MESP) on the Connolly surface were specified to provide information on the charge distribution of the substituted anilides. The interrelation between electrostatic and lipophilicity potentials on molecular surfaces was reported previously [56]. The electron-rich positions seem to appear at low, possibly negative, electrostatic potential energy values (see Figure 7). In other words, low MESP values indicate molecular areas susceptible to electrophilic attack (nucleophilic positions), while greater electrostatic values correspond to electrophilic positions. Noticeably, the negative MESP values (dark blue areas) in the close proximity of the substituted anilide ring seem to contribute to the MIC activity of molecule 10. Obviously, the introduction and composition of electronegative or electropositive substituents have an impact on the lipophilicity values as well.

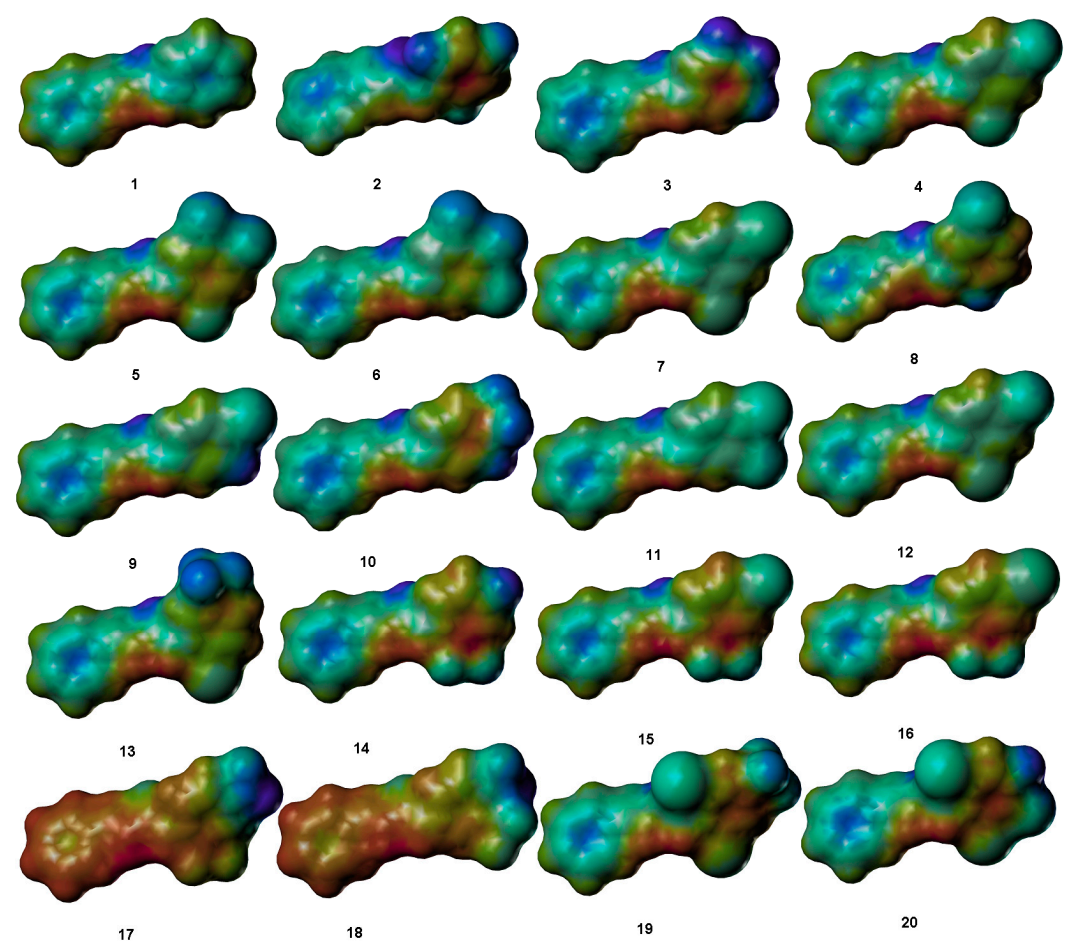

Figure 7. Molecular electrostatic potential topography of 1-20 anilides. Blue color codes negative values; red color codes positive MESP values. 
The spatial MESP distribution does not provide a practical tool for molecular comparison; therefore, simpler, comparative 2D Kohonen maps of the entire molecular surface were generated [57]. Self-organizing Kohonen neural mapping (SOM) is a nonlinear projection procedure that reduces the input data dimensionality (e.g., converts $3 \mathrm{D}$ objects to $2 \mathrm{D}$ ), while preserving the topological relationships between the input and output data [58]. Moreover, a trained network can be engaged to project the specified molecular property (expressed as a vector) by generating a 2D color-coded clustering pattern called a feature map. The SOM algorithm was employed to generate an electrostatic potential map in the form of a two-dimensional topographic pattern produced from input signals (points) that were sampled randomly at the molecular surface as illustrated in Figure 8. The substitution of the anilide ring by a rather bulky motif (e.g.,- $-\mathrm{CF}_{3}$ ) was preferred for the anti-inflammatory potential and lipophilic compound property; therefore, a mono-trifluoro- methyl-based molecule with highly electronegative substituent (e.g.,-F) was chosen as a template (the most active molecule 10) to proceed the remaining (counter-template) molecules. The structural inconsistences (dissimilarities) within the analyzed set of compounds are indicated by the number of inactive (empty/white) neurons in the map (see Figure 8). Unfortunately, there are no clear and visible variations in the surface charge distribution within $40 \times 40$ maps between substituted analogues, with exception of molecules $\mathbf{1 7}$ and 18. Not surprisingly, the lowest number of non-active neurons of the comparative maps (less than 200 out of 1600) is prescribed to the similarly substituted (position 3 and 4 of the anilide ring) molecules 9, 11, and 18.

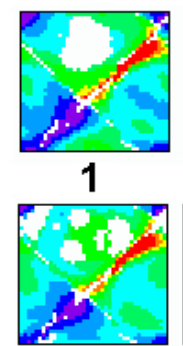

5

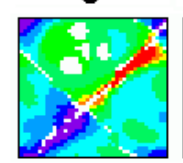

9

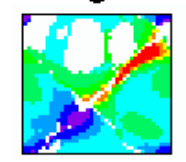

13

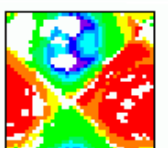

17

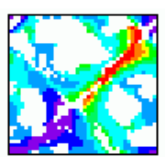

2

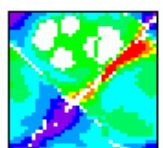

6

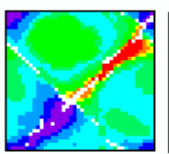

10

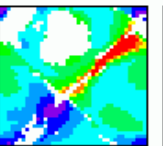

14

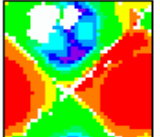

18

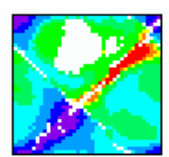

3

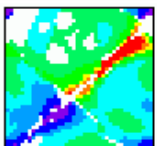

7

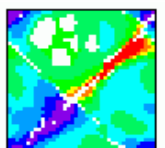

11

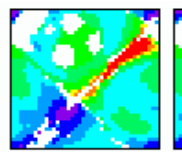

12
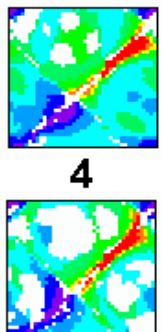

8
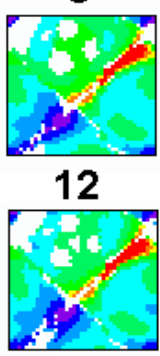

15

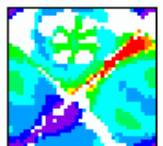

19
4

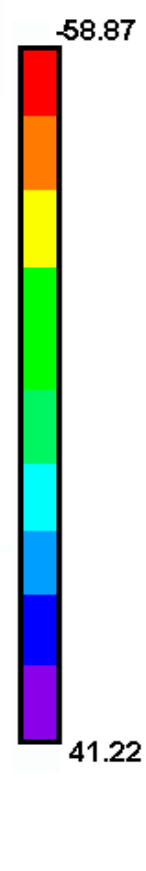

20

Figure 8. Comparative SOM $40 \times 40$ maps for 1-20 anilides. Colors code MESP values, white color indicates non-active neurons.

\section{Materials and Methods}

\subsection{Chemistry}

\subsubsection{General Information}

All reagents were purchased from Merck (Sigma-Aldrich, St. Louis, MO, USA) or Alfa (Alfa-Aesar, Ward Hill, MA, USA). Reactions were performed using a CEM Discover SP microwave reactor (CEM, 
Matthews, NC, USA). Melting points were determined on an apparatus Stuart SMP10 (Stone, UK) and are uncorrected. Infrared (IR) spectra were recorded on an ATR Zn/Se for a Nicolet ${ }^{\mathrm{TM}}$ iS 5 FT-IR spectrometer (Thermo Fisher Scientific, West Palm Beach, FL, USA). The spectra were obtained by the accumulation of 64 scans with $4 \mathrm{~cm}^{-1}$ resolution in the region of $4000-400 \mathrm{~cm}^{-1}$. All ${ }^{1} \mathrm{H}$ - and ${ }^{13} \mathrm{C}-\mathrm{NMR}$ spectra were recorded on a JEOL JNM-ECA 600II NMR spectrometer $\left(600 \mathrm{MHz}\right.$ for ${ }^{1} \mathrm{H}$ and $150 \mathrm{MHz}$ for ${ }^{13} \mathrm{C}$, Jeol, Tokyo, Japan) in dimethyl sulfoxide- $d_{6}$ (DMSO- $\left.d_{6}\right) ;{ }^{1} \mathrm{H}$ and ${ }^{13} \mathrm{C}$ chemical shifts $(\delta)$ are reported in ppm. High-resolution mass spectra were measured using a high-performance liquid chromatograph Dionex UltiMate ${ }^{\circledR} 3000$ (Thermo Scientific, West Palm Beach, FL, USA) coupled with an LTQ Orbitrap $\mathrm{XL}^{\mathrm{TM}}$ Hybrid Ion Trap-Orbitrap Fourier Transform Mass Spectrometer (Thermo Scientific) equipped with a HESI II (heated electrospray ionization) source in the negative mode.

\subsubsection{Synthesis}

Cinnamic acid $(3.37 \mathrm{mM})$ was suspended at room temperature in dry chlorobenzene $(20 \mathrm{~mL})$ inside a microwave tube, where phosphorus trichloride $(1.7 \mathrm{mM})$ and the corresponding aniline derivative $(3.37 \mathrm{mM})$ were added dropwise. Following this step, a magnetic stirrer was added to the tube and the reaction mixture was transferred to the microwave reactor (max. $500 \mathrm{~W}$ ) at $130{ }^{\circ} \mathrm{C}$ for $30 \mathrm{~min}$, where the synthesis at elevated pressure was performed. After the mixture was cooled to $60^{\circ} \mathrm{C}$, the solvent was evaporated in vacuum. A solid residue was washed with $2 \mathrm{M} \mathrm{HCl}$, and a crude product was recrystallized, using $96 \%$ ethanol first, and then $50 \%$ ethanol $[26,28]$.

(2E)-N-Phenyl-3-phenylprop-2-enamide (1) was described previously by Pospisilova et al. [26].

(2E)-3-Phenyl-N-(2,4,6-trifluorophenyl)prop-2-enamide (2), Yield 72\%; Mp 134-136 ${ }^{\circ} \mathrm{C}$; IR ( $\left.\mathrm{cm}^{-1}\right)$ : 3244, $3078,3024,1659,1631,1612,1525,1443,1336,1239,1177,1124,1045,999,972,861,843,764,751,705$, 666, 612, 572, 533, 513, 481; ${ }^{1} \mathrm{H}-\mathrm{NMR}$ (DMSO- $\left.d_{6}\right), \delta: 9.91(\mathrm{~s}, 1 \mathrm{H}), 7.65-7.64(\mathrm{~m}, 2 \mathrm{H}), 7.61(\mathrm{~d}, J=15.8 \mathrm{~Hz}$, 1H), 7.47-7.41 (m, 3H), $7.32(\mathrm{t}, J=8.2 \mathrm{~Hz}, 2 \mathrm{H}), 6.85(\mathrm{~d}, J=15.8 \mathrm{~Hz}, 1 \mathrm{H}) ;{ }^{13} \mathrm{C}-\mathrm{NMR}$ (DMSO- $\left.d_{6}\right), \delta: 163.95$, $159.93(\mathrm{~d}, J=245.7 \mathrm{~Hz}), 157.88(\mathrm{ddd}, J=250.0 \mathrm{~Hz}, 15.9 \mathrm{~Hz}, 8.7 \mathrm{~Hz}), 141.19,134.44,130.02,129.03$, $127.87,120.35,111.48(\mathrm{td}, J=17.3 \mathrm{~Hz}, J=5.8 \mathrm{~Hz}), 100.95$ (m) (Figure S1); HR-MS: $\mathrm{C}_{15} \mathrm{H}_{9} \mathrm{ONF}_{3}[\mathrm{M}-\mathrm{H}]^{-}$ calculated $276.0642 \mathrm{~m} / \mathrm{z}$, found $276.0634 \mathrm{~m} / \mathrm{z}$ (Figure S2).

(2E)-3-Phenyl-N-(3,4,5-trifluorophenyl)prop-2-enamide (3), Yield 74\%; Mp $169-17{ }^{\circ} \mathrm{C}$; IR $\left(\mathrm{cm}^{-1}\right)$ : 3303, 1661, 1617, 1545, 1530, 1451, 1426, 1338, 1238, 1208, 1195, 1044, 1013, 976, 858, 848, 805, 770, 761, 717, 642, 628, 561, 509, 481; ${ }^{1} \mathrm{H}-\mathrm{NMR}$ (DMSO- $\left.d_{6}\right), \delta: 10.58(\mathrm{~s}, 1 \mathrm{H}), 7.64-7.67(\mathrm{~m}, 5 \mathrm{H}), 7.46-7.41(\mathrm{~m}, 3 \mathrm{H}), 6.74$ $(\mathrm{d}, J=15.8 \mathrm{~Hz}, 1 \mathrm{H}) ;{ }^{13} \mathrm{C}-\mathrm{NMR}\left(\mathrm{DMSO}-d_{6}\right), \delta: 164.02,150.09(\mathrm{ddd}, J=244.2 \mathrm{~Hz}, J=10.1 \mathrm{~Hz}, J=5.8 \mathrm{~Hz})$, $141.33,135.56(\mathrm{td}, J=11.6 \mathrm{~Hz}, J=4.3 \mathrm{~Hz}), 134.70(\mathrm{dt}, J=244.2 \mathrm{~Hz}, J=15.9 \mathrm{~Hz}), 134.38,130.10,129.05$, 127.89, 121.25, 103.45 (m) (Figure S3); HR-MS: $\mathrm{C}_{15} \mathrm{H}_{9} \mathrm{ONF}_{3}[\mathrm{M}-\mathrm{H}]^{-}$calculated $276.0642 \mathrm{~m} / \mathrm{z}$, found $276.0633 \mathrm{~m} / \mathrm{z}$ (Figure S4).

(2E)-N-(2,4-Dichlorophenyl)-3-phenylprop-2-enamide (4), Yield: $62 \%$; Mp $159-161{ }^{\circ} \mathrm{C}$; $\mathrm{IR}\left(\mathrm{cm}^{-1}\right)$ : 3264 , 3071, 3027, 1654, 1620, 1578, 1524, 1471, 1448, 1380, 1335, 1283, 1238, 1202, 1182, 1144, 1099, 1072, 1053, 1029, 1005, 999, 969, 858, 826, 787, 757, 725, 710, 697, 658, 632, 560, 559, 513, 488, 445; ${ }^{1} \mathrm{H}-\mathrm{NMR}$ (DMSO- $\left.d_{6}\right), \delta: 9.78(\mathrm{~s}, 1 \mathrm{H}), 7.98(\mathrm{~d}, J=8.9 \mathrm{~Hz}, 1 \mathrm{H}), 7.69(\mathrm{~d}, J=2.1 \mathrm{~Hz}, 1 \mathrm{H}), 7.65-7.64(\mathrm{~m}, 2 \mathrm{H}), 7.62,(\mathrm{~d}$, $J=15.8 \mathrm{~Hz}, 1 \mathrm{H}), 7.47-7.41(\mathrm{~m}, 4 \mathrm{H}), 7.11(\mathrm{~d}, J=15.8 \mathrm{~Hz}, 1 \mathrm{H}) ;{ }^{13} \mathrm{C}-\mathrm{NMR}$ (DMSO- $\left.d_{6}\right), \delta: 164.02,141.17$, 134.62, 134.21, 129.99, 129.09, 129.05, 128.95, 127.88, 127.59, 126.57, 126.43, 121.54 (Figure S5); HR-MS: $\mathrm{C}_{15} \mathrm{H}_{10} \mathrm{ONCl}_{2}[\mathrm{M}-\mathrm{H}]^{-}$calculated $290.01450 \mathrm{~m} / \mathrm{z}$, found $290.0140 \mathrm{~m} / \mathrm{z}$ (Figure S6).

(2E)-3-Phenyl-N-(2,4,5-trichlorophenyl)prop-2-enamide (5), Yield: 52\%; $\mathrm{Mp} 170-172{ }^{\circ} \mathrm{C} ; \mathrm{IR}\left(\mathrm{cm}^{-1}\right)$ : 3265, 3107, 3061, 3011, 1656, 1629, 1600, 1568, 1511, 1456, 1446, 1364, 1281, 1248, 1202, 1181, 1129, 1074, 1031, 962, 942, 880, 855, 798, 756, 729, 706, 688, 675, 631, 579, 564, 499, 465, 448; ${ }^{1}$ H-NMR (DMSO- $\left.d_{6}\right), \delta:$ $9.85(\mathrm{~s}, 1 \mathrm{H}), 8.33(\mathrm{~s}, 1 \mathrm{H}), 7.94(\mathrm{~s}, 1 \mathrm{H}), 7.66-7.65(\mathrm{~m}, 2 \mathrm{H}), 7.64(\mathrm{~d}, J=15.8 \mathrm{~Hz}, 1 \mathrm{H}), 7.48-7.42(\mathrm{~m}, 3 \mathrm{H})$, $7.16(\mathrm{~d}, J=15.8 \mathrm{~Hz}, 1 \mathrm{H}) \cdot ;{ }^{13} \mathrm{C}-\mathrm{NMR}\left(\mathrm{DMSO}-d_{6}\right), \delta: 164.23,141.68,135.18,134.52,130.55,130.12,129.84$, 
129.05, 127.95, 126.89, 125.31, 124.45, 121.29 (Figure S7); HR-MS: $\mathrm{C}_{15} \mathrm{H}_{9} \mathrm{ONCl}_{3}[\mathrm{M}-\mathrm{H}]^{-}$calculated $323.9755 \mathrm{~m} / \mathrm{z}$, found $323.9751 \mathrm{~m} / \mathrm{z}$ (Figure S8).

(2E)-3-Phenyl-N-(3,4,5-trichlorophenyl)prop-2-enamide (6), Yield: 75\%; Mp 237-239 ${ }^{\circ} \mathrm{C}$; IR $\left(\mathrm{cm}^{-1}\right)$ : 3157, 3080, 1655, 1613, 1583, 1513, 1433, 1378, 1337, 1281, 1245, 1196, 1188, 1148, 1011, 998, 967, 944, 880, 860, 815, 762, 711, 685, 617, 602, 575, 536, 483; ${ }^{1} \mathrm{H}-\mathrm{NMR}$ (DMSO- $d_{6}$ ), $\delta: 10.62$ (s, 1H), 7.95 (s, 2H), 7.65-7.62 $(\mathrm{m}, 3 \mathrm{H}), 7.47-7.42(\mathrm{~m}, 3 \mathrm{H}), 6.74(\mathrm{~d}, J=15.8 \mathrm{~Hz}, 1 \mathrm{H}) ;{ }^{13} \mathrm{C}-\mathrm{NMR}$ (DMSO- $\left.d_{6}\right), \delta: 164.16,141.63,139.28$, 134.31, 132.91, 130.20, 129.08, 127.96, 123.40, 121.14, 119.19 (Figure S9); HR-MS: $\mathrm{C}_{15} \mathrm{H}_{9} \mathrm{ONCl}_{3}[\mathrm{M}-\mathrm{H}]^{-}$ calculated $323.9755 \mathrm{~m} / \mathrm{z}$, found $323.9752 \mathrm{~m} / \mathrm{z}$ (Figure S10).

(2E)-N-(2,4-Dibromophenyl)-3-phenylprop-2-enamide (7), Yield: 49\%; Mp 180-182 ${ }^{\circ} \mathrm{C}$; IR $\left(\mathrm{cm}^{-1}\right)$ : 3263, 2980, 2888, 1653, 1620, 1575, 1521, 1464, 1446, 1376, 1336, 1280, 1240, 1203, 1184, 1080, 1040, 1007, 967, $859,825,766,755,711,688,643,619,566,546,501,472,440 ;{ }^{1} \mathrm{H}-\mathrm{NMR}$ (DMSO- $\left.d_{6}\right), 8: 9.68(\mathrm{~s}, 1 \mathrm{H}), 7.94(\mathrm{~d}$, $J=2.1 \mathrm{~Hz}, 1 \mathrm{H}), 7.78(\mathrm{~d}, J=8.9 \mathrm{~Hz}, 1 \mathrm{H}), 7.65-7.60(\mathrm{~m}, 4 \mathrm{H}), 7.47-7.41(\mathrm{~m}, 3 \mathrm{H}), 7.06(\mathrm{~d}, J=15.8 \mathrm{~Hz}, 1 \mathrm{H})$; ${ }^{13}$ C-NMR (DMSO- $\left.d_{6}\right), \delta: 163.93,141.13,135.88,134.61,134.55,130.98,129.99,129.05,127.88,127.73$, 121.50, 117.97, 117.66 (Figure S11); HR-MS: $\mathrm{C}_{15} \mathrm{H}_{10} \mathrm{ONBr}_{2}[\mathrm{M}-\mathrm{H}]^{-}$calculated $377.9134 \mathrm{~m} / \mathrm{z}$, found $377.9106 \mathrm{~m} / \mathrm{z}$ (Figure S12).

(2E)-N-(5-Chloro-2-fluorophenyl)-3-phenylprop-2-enamide (8), Yield: 59\%; $\mathrm{Mp} 118-120{ }^{\circ} \mathrm{C} ; \mathrm{IR}\left(\mathrm{cm}^{-1}\right)$ : 3244, $3188,3119,3042,1663,1622,1612,1541,1481,1415,1343,1268,1253,1202,1182,1112,996,915,871,808$, 761, 737, 679, 646, 574, 566, 502, 485, 454; ${ }^{1} \mathrm{H}-\mathrm{NMR}$ (DMSO- $d_{6}$ ), $\delta: 10.13$ (s, $\left.1 \mathrm{H}\right), 8.31$ (dd, $J=6.9 \mathrm{~Hz}$, $J=2.7 \mathrm{~Hz}, 1 \mathrm{H}), 7.64-7.61(\mathrm{~m}, 3 \mathrm{H}), 7.47-7.41(\mathrm{~m}, 3 \mathrm{H}), 7.35(\mathrm{dd}, J=11.0 \mathrm{~Hz}, J=8.9 \mathrm{~Hz}, 1 \mathrm{H}), 7.22-7.19(\mathrm{~m}$, $1 \mathrm{H}), 7.11(\mathrm{~d}, J=15.8 \mathrm{~Hz}, 1 \mathrm{H}){ }^{13} \mathrm{C}-\mathrm{NMR}\left(\mathrm{DMSO}-d_{6}\right), \delta: 164.22,151.55(\mathrm{~d}, J=245.6 \mathrm{~Hz}), 141.31,134.58$, $130.04,129.06,128.02(\mathrm{~d}, J=2.9 \mathrm{~Hz}), 127.89(\mathrm{~d}, J=13.0 \mathrm{~Hz}), 127.87,124.14(\mathrm{~d}, J=7.2 \mathrm{~Hz}), 122.23,121.48$, $116.98\left(\mathrm{~d}, J=21.7 \mathrm{~Hz}\right.$ ) (Figure S13); HR-MS: $\mathrm{C}_{15} \mathrm{H}_{10} \mathrm{ONClF}[\mathrm{M}-\mathrm{H}]^{-}$calculated $274.0440 \mathrm{~m} / \mathrm{z}$, found $274.0435 \mathrm{~m} / \mathrm{z}$ (Figure S14).

(2E)-N-(4-Bromo-3-fluorophenyl)-3-phenylprop-2-enamide (9), Yield: 69\%; Mp 146-148 ${ }^{\circ} \mathrm{C}$; IR ( $\left.\mathrm{cm}^{-1}\right)$ : 3405, 1673, 1625, 1598, 1514, 1473, 1450, 1414, 1333, 1302, 1240, 1204, 1190, 1155, 1135, 1045, 988, 976, 944, 868, 857, 812, 780, 763, 738, 707, 683, 642, 572, 564, 544, 518, 518; ${ }^{1} \mathrm{H}-\mathrm{NMR}$ (DMSO-d 6 ), $\delta: 10.55$ (s, 1H), 7.89 $(\mathrm{dd}, J=8.9 \mathrm{~Hz}, J=4.0 \mathrm{~Hz}, 1 \mathrm{H}), 7.67-7.61(\mathrm{~m}, 4 \mathrm{H}), 7.47-7.41(\mathrm{~m}, 3 \mathrm{H}), 7.36(\mathrm{dd}, J=8.9 \mathrm{~Hz}, J=2.1 \mathrm{~Hz}$, $1 \mathrm{H}), 6.79(\mathrm{~d}, J=15.8 \mathrm{~Hz}, 1 \mathrm{H}) ;{ }^{13} \mathrm{C}-\mathrm{NMR}\left(\mathrm{DMSO}-d_{6}\right), \delta: 163.95,158.08(\mathrm{~d}, J=242.8 \mathrm{~Hz}), 141.13,140.43(\mathrm{~d}$, $J=10.1 \mathrm{~Hz}), 134.48,133.41,130.06,129.08,127.88,121.54,116.59(\mathrm{~d}, J=2.9 \mathrm{~Hz}), 107.19(\mathrm{~d}, J=26.0 \mathrm{~Hz})$, $100.83\left(\mathrm{~d}, \mathrm{~J}=21.7 \mathrm{~Hz}\right.$ ) (Figure S15); HR-MS: $\mathrm{C}_{15} \mathrm{H}_{10} \mathrm{ONBrF}[\mathrm{M}-\mathrm{H}]^{-}$calculated $317.9935 \mathrm{~m} / \mathrm{z}$, found $317.9929 \mathrm{~m} / \mathrm{z}$ (Figure S16).

(2E)-N-[3-Fluoro-4-(trifluoromethyl)phenyl]-3-phenylprop-2-enamide (10), Yield 69\%; Mp 139-141 ${ }^{\circ} \mathrm{C}$; IR $\left(\mathrm{cm}^{-1}\right): 8336,1671,1624,1560,1521,1506,1452,1424,1413,1338,1319,1205,1192,1162,1117,1049$, 996, 970, 666, 827, 767, 763, 738, 710, 633, 603, 565, 536, 507, 484; ${ }^{1} \mathrm{H}-\mathrm{NMR}$ (DMSO- $\left.d_{6}\right), \delta: 10.78(\mathrm{~s}, 1 \mathrm{H})$, $7.95(\mathrm{dd}, J=13.7 \mathrm{~Hz}, 1 \mathrm{H}), 7.75(\mathrm{t}, J=8.6 \mathrm{~Hz}, 1 \mathrm{H}), 7.67(\mathrm{~d}, J=15.8 \mathrm{~Hz}, 1 \mathrm{H}), 7.68-7.65(\mathrm{~m}, 2 \mathrm{H}), 7.54(\mathrm{~d}$, $J=8.2 \mathrm{~Hz}, 1 \mathrm{H}), 7.48-7.42(\mathrm{~m}, 3 \mathrm{H}), 6.82(\mathrm{~d}, J=15.8 \mathrm{~Hz}, 1 \mathrm{H}) ;{ }^{13} \mathrm{C}-\mathrm{NMR}\left(\mathrm{DMSO}-d_{6}\right), \delta: 164.33,159.20(\mathrm{dq}$, $J=248.5 \mathrm{~Hz}, J=2.9 \mathrm{~Hz}), 144.96(\mathrm{~d}, J=11.6 \mathrm{~Hz}), 141.74,134.36,130.20,129.08,127.95,127.87(\mathrm{~m}), 122.82$ $(\mathrm{q}, J=271.7 \mathrm{~Hz}), 121.25,114.75,110.57(\mathrm{qd}, J=31.8 \mathrm{~Hz}, J=11.6 \mathrm{~Hz}), 106.65(\mathrm{~d}, J=26.1 \mathrm{~Hz})$ (Figure S17); HR-MS: $\mathrm{C}_{16} \mathrm{H}_{10} \mathrm{ONF}_{4}[\mathrm{M}-\mathrm{H}]^{-}$calculated $308.0704 \mathrm{~m} / \mathrm{z}$, found $308.0695 \mathrm{~m} / \mathrm{z}$ (Figure S18).

(2E)-N-(4-Bromo-3-chlorophenyl)-3-phenylprop-2-enamide (11), Yield: 61\%; Mp 170-172 ${ }^{\circ} \mathrm{C}$; IR $\left(\mathrm{cm}^{-1}\right)$ : $3282,3097,2980,2888,1663,1627,1579,1521,1470,1449,1376,1338,1288,1253,1229,1180,1113,1071$, $968,882,861,808,761,711,679,676,577,561,496,482 ;{ }^{1} \mathrm{H}-\mathrm{NMR}$ (DMSO-d $\left.d_{6}\right), \delta: 10.51(\mathrm{~s}, 1 \mathrm{H}), 8.11(\mathrm{~d}$, $J=2.1 \mathrm{~Hz}, 1 \mathrm{H}), 7.72(\mathrm{~d}, J=8.2 \mathrm{~Hz}, 1 \mathrm{H}), 7.65-7.61(\mathrm{~m}, 3 \mathrm{H}), 7.50(\mathrm{dd}, J=8.6 \mathrm{~Hz}, J=2.4 \mathrm{~Hz}, 1 \mathrm{H}), 7.47-7.41$ $(\mathrm{m}, 3 \mathrm{H}), 6.78(\mathrm{~d}, J=15.8 \mathrm{~Hz}, 1 \mathrm{H}) ;{ }^{13} \mathrm{C}-\mathrm{NMR}\left(\mathrm{DMSO}_{-} \mathrm{d}_{6}\right), 8: 163.94,141.13,139.92,134.47,133.95,133.09$, 
$130.07,129.08,127.88,121.53,120.31,119.45,114.48$ (Figure S19); HR-MS: $\mathrm{C}_{15} \mathrm{H}_{10} \mathrm{ONBrCl}[\mathrm{M}-\mathrm{H}]^{-}$ calculated $333.9640 \mathrm{~m} / \mathrm{z}$, found $333.9635 \mathrm{~m} / \mathrm{z}$ (Figure S20).

(2E)-N-(2-Bromo-4-chlorophenyl)-3-phenylprop-2-enamide (12), Yield: $68 \%$; $\mathrm{Mp} 173-175{ }^{\circ} \mathrm{C}$; IR $\left(\mathrm{cm}^{-1}\right)$ : 3258, 2980, 2888, 1653, 1621, 1572, 1524, 1465, 1447, 1380, 1336, 1279, 1263, 1238, 1201, 1180, 1093, 1039, 1006, 999, 969, 858, 824, 775, 757, 714, 700, 653, 632, 568, 551, 512; ${ }^{1} \mathrm{H}-\mathrm{NMR}$ (DMSO- $d_{6}$ ), $\delta: 9.69(\mathrm{~s}, 1 \mathrm{H}$ ), $7.84-7.82(\mathrm{~m}, 2 \mathrm{H}), 7.65-7.64(\mathrm{~m}, 2 \mathrm{H}), 7.62(\mathrm{~d}, J=15.8 \mathrm{~Hz}, 1 \mathrm{H}), 7.49(\mathrm{dd}, J=8.6 \mathrm{~Hz}, J=2.4 \mathrm{~Hz}, 1 \mathrm{H})$, 7.47-7.41 (m, 3H), $7.07(\mathrm{~d}, J=15.8 \mathrm{~Hz}, 1 \mathrm{H}) ;{ }^{13} \mathrm{C}-\mathrm{NMR}$ (DMSO- $\left.d_{6}\right), \delta: 163.94,141.08,135.50,134.60$, 131.87, 129.96, 129.72, 129.02, 128.05, 127.85, 127.38, 121.49, 117.69 (Figure S21); HR-MS: $\mathrm{C}_{15} \mathrm{H}_{10} \mathrm{ONBrCl}$ $[\mathrm{M}-\mathrm{H}]^{-}$calculated $333.9640 \mathrm{~m} / \mathrm{z}$, found $333.9635 \mathrm{~m} / \mathrm{z}$ (Figure S22).

(2E)-N-[2-Bromo-5-(trifluoromethyl)phenyl]-3-phenylprop-2-enamide (13), Yield 59\%; Mp 134-135 ${ }^{\circ} \mathrm{C}$; IR $\left(\mathrm{cm}^{-1}\right): 3270,1658,1631,1606,1529,1467,1423,1329,1262,1170,1112,1078,1035,963,928,894,856,816$, 759, 709, 685, 643, 615, 560, 491, 454; ${ }^{1} \mathrm{H}-\mathrm{NMR}\left(\mathrm{DMSO}_{-} \mathrm{d}_{6}\right), \delta: 9.84(\mathrm{~s}, 1 \mathrm{H}), 8.26(\mathrm{~d}, J=1.4 \mathrm{~Hz}, 1 \mathrm{H}), 7.94(\mathrm{~d}$, $J=8.2 \mathrm{~Hz}, 1 \mathrm{H}), 7.67-7.65(\mathrm{~m}, 2 \mathrm{H}), 7.65(\mathrm{~d}, J=15.8 \mathrm{~Hz}, 1 \mathrm{H}), 7.49-7.42(\mathrm{~m}, 4 \mathrm{H}), 7.14(\mathrm{~d}, J=15.8 \mathrm{~Hz}, 1 \mathrm{H})$; ${ }^{13}$ C-NMR (DMSO- $\left.d_{6}\right), \delta: 164.25,141.54,137.26,134.54,134.06,130.08,129.06,128.59(q, J=31.8 \mathrm{~Hz})$, $127.94,123.71(\mathrm{q}, J=273.1 \mathrm{~Hz}), 122.77(\mathrm{q}, J=4.3 \mathrm{~Hz}), 122.07(\mathrm{q}, J=2.9 \mathrm{~Hz}), 121.35,120.81$ (Figure S23); HR-MS: $\mathrm{C}_{16} \mathrm{H}_{10} \mathrm{ONBrF}_{3}[\mathrm{M}-\mathrm{H}]^{-}$calculated $367.9903 \mathrm{~m} / \mathrm{z}$, found $367.9893 \mathrm{~m} / \mathrm{z}$ (Figure S24).

(2E)-N-[4-Fluoro-2-(trifluoromethyl)phenyl]-3-phenylprop-2-enamide (14), Yield 76\%; Mp 145-147 ${ }^{\circ} \mathrm{C}$; IR $\left(\mathrm{cm}^{-1}\right): 3257,3086,1653,1622,1521,1492,1429,1332,1316,1271,146,1174,1127,1119,1049,974,914$, 883, 865, 845, 823, 761, 745, 727, 709, 691, 664, 652, 569, 539, 499, 481; ${ }^{1} \mathrm{H}-\mathrm{NMR}$ (DMSO- $d_{6}$ ), $8: 9.79$ (s, $1 \mathrm{H}), 7.67(\mathrm{dd}, J=8.9 \mathrm{~Hz}, J=2.7 \mathrm{~Hz}, 1 \mathrm{H}), 7.65-7.63(\mathrm{~m}, 2 \mathrm{H}), 7.61-7.58(\mathrm{~m}, 2 \mathrm{H}), 7.59(\mathrm{~d}, J=15.8 \mathrm{~Hz}, 1 \mathrm{H})$, $7.46-7.40(\mathrm{~m}, 3 \mathrm{H}), 6.97(\mathrm{~d}, J=15.8 \mathrm{~Hz}, 1 \mathrm{H}) ;{ }^{13} \mathrm{C}-\mathrm{NMR}\left(\mathrm{DMSO}-d_{6}\right), \delta: 164.79,159.51(\mathrm{~d}, J=245.7 \mathrm{~Hz})$, $140.86,134.55,132.54(\mathrm{~d}, J=8.7 \mathrm{~Hz}), 131.76(\mathrm{~d}, J=2.9 \mathrm{~Hz}), 129.92,129.02,127.81,126.40(\mathrm{qd}, J=31.8 \mathrm{~Hz}$, $J=10.1 \mathrm{~Hz}), 122.67(\mathrm{qd}, J=274.6 \mathrm{~Hz}, J=2.9 \mathrm{~Hz}), 121.18,120.00(\mathrm{~d}, J=21.7 \mathrm{~Hz}), 113.72(\mathrm{dq}, J=26.0 \mathrm{~Hz}$, $J=5.8 \mathrm{~Hz}$ ) (Figure S25); HR-MS: $\mathrm{C}_{16} \mathrm{H}_{10} \mathrm{ONF}_{4}[\mathrm{M}-\mathrm{H}]^{-}$calculated $308.0704 \mathrm{~m} / \mathrm{z}$, found $308.0696 \mathrm{~m} / \mathrm{z}$ (Figure S26).

(2E)-N-[4-Chloro-2-(trifluoromethyl)phenyl]-3-phenylprop-2-enamide (15), Yield 71\%; Mp 165-167 ${ }^{\circ} \mathrm{C}$; IR $\left(\mathrm{cm}^{-1}\right)$ : 3268, 3083, 3030, 1655, 1624, 1584, 1522, 1483, 1449, 1410, 1337, 1306, 1277, 1268, 1243, 1171, 1122, $1109,1052,967,890,872,857,833,810,761,711,696,684,562,539,509 ;{ }^{1} \mathrm{H}-\mathrm{NMR}$ (DMSO- $d_{6}$ ), $8: 9.80$ (s, $1 \mathrm{H}), 7.84(\mathrm{~d}, J=2.1 \mathrm{~Hz}, 1 \mathrm{H}), 7.79(\mathrm{dd}, J=8.6 \mathrm{~Hz}, J=2.4 \mathrm{~Hz}, 1 \mathrm{H}), 7.69(\mathrm{~d}, J=8.9 \mathrm{~Hz}, 1 \mathrm{H}), 7.65-7.64$ $(\mathrm{m}, 2 \mathrm{H}), 7.60(\mathrm{~d}, J=15.8 \mathrm{~Hz}, 1 \mathrm{H}), 7.47-7.41(\mathrm{~m}, 3 \mathrm{H}), 7.00(\mathrm{~d}, J=15.8 \mathrm{~Hz}, 1 \mathrm{H}) ;{ }^{13} \mathrm{C}-\mathrm{NMR}\left(\right.$ DMSO- $\left.d_{6}\right)$. $\delta: 164.65,141.13,134.52,134.38,132.96,131.51,130.67,129.98,129.03,127.86,126.26(\mathrm{q}, J=5.8 \mathrm{~Hz})$, $125.72(\mathrm{q}, J=30.3 \mathrm{~Hz}), 122.7(\mathrm{q}, J=273.1 \mathrm{~Hz}), 121.12$ (Figure S27); HR-MS: $\mathrm{C}_{16} \mathrm{H}_{10} \mathrm{ONClF}_{3}[\mathrm{M}-\mathrm{H}]^{-}$ calculated $324.0409 \mathrm{~m} / \mathrm{z}$, found $324.0399 \mathrm{~m} / \mathrm{z}$ (Figure S28).

(2E)-N-[4-Bromo-2-(trifluoromethyl)phenyl]-3-phenylprop-2-enamide (16), Yield 64\%; Mp 176-178 ${ }^{\circ} \mathrm{C}$; IR $\left(\mathrm{cm}^{-1}\right)$ : 3289, 3083, 3030, 1657, 1624, 1525, 1481, 1404, 1338, 1305, 1278, 1265, 1247, 1172, 1160, 1124, $1052,967,889,866,831,760,747,710,682,631,560,529,501,463 ;{ }^{1} \mathrm{H}-\mathrm{NMR}$ (DMSO- $\left.d_{6}\right), \delta: 9.78(\mathrm{~s}$, $1 \mathrm{H}), 7.94(\mathrm{~m}, 1 \mathrm{H}), 7.92(\mathrm{dd}, J=8.2 \mathrm{~Hz}, J=2.1 \mathrm{~Hz}, 1 \mathrm{H}), 7.65-7.62(\mathrm{~m}, 3 \mathrm{H}), 7.60(\mathrm{~d}, J=15.8 \mathrm{~Hz}, 1 \mathrm{H})$, 7.46-7.41 (m, 3H), $7.00(\mathrm{~d}, J=15.8 \mathrm{~Hz}, 1 \mathrm{H}) ;{ }^{13} \mathrm{C}-\mathrm{NMR}\left(\mathrm{DMSO}-d_{6}\right), \delta: 164.59,141.16,135.94,134.81$ (q, $J=2.9 \mathrm{~Hz}), 134.52,131.64,129.99,129.03,129.02(\mathrm{q}, J=5.8 \mathrm{~Hz}), 127.86,125.87(\mathrm{q}, J=30.3 \mathrm{~Hz}), 122.60(\mathrm{q}$, $J=273.1 \mathrm{~Hz}$ ), 121.12, 118.62 (Figure S29); HR-MS: $\mathrm{C}_{16} \mathrm{H}_{10} \mathrm{ONBrF}_{3}[\mathrm{M}-\mathrm{H}]^{-}$calculated $367.9903 \mathrm{~m} / \mathrm{z}$, found $367.9894 \mathrm{~m} / \mathrm{z}$ (Figure S30).

(2E)-N-[4-Nitro-2-(trifluoromethyl)phenyl]-3-phenylprop-2-enamide (17), Yield 61\%; Mp 164-166 ${ }^{\circ} \mathrm{C}$; IR $\left(\mathrm{cm}^{-1}\right)$ : 3314, 3086, 1662, 1620, 1594, 1544, 1505, 1449, 1424, 1338, 1319, 1277, 1172, 1112, 1052, 1000, 973, 921, 901, 854, 840, 790, 760, 744, 709, 686, 604, 592, 560; ${ }^{1} \mathrm{H}-\mathrm{NMR}$ (DMSO- $d_{6}$ ), $\delta: 9.95$ (s, 1H), 8.54 $(\mathrm{dd}, J=8.9 \mathrm{~Hz}, J=2.7 \mathrm{~Hz}, 1 \mathrm{H}), 8.47(\mathrm{~d}, J=2.7 \mathrm{~Hz}, 1 \mathrm{H}), 8.17(\mathrm{~d}, J=8.9 \mathrm{~Hz}, 1 \mathrm{H}), 7.68(\mathrm{~d}, J=15.8 \mathrm{~Hz}$, 
1H), 7.68-7.67 (m, 2H), 7.48-7.43 (m, 3H), $7.17(\mathrm{~d}, J=15.8 \mathrm{~Hz}, 1 \mathrm{H}) ;{ }^{13} \mathrm{C}-\mathrm{NMR}$ (DMSO- $\left.d_{6}\right), \delta:$ 164.64, 143.84, 142.29, 141.30, 134.41, 130.25, 129.06, 128.84, 128.04, 127.96, 122.50 (q, J = 30.3 Hz), 122.48 (q, $J=273.10 \mathrm{~Hz}$ ), $122.27(\mathrm{q}, J=4.3 \mathrm{~Hz}), 120.91$ (Figure S31); HR-MS: $\mathrm{C}_{16} \mathrm{H}_{10} \mathrm{O}_{3} \mathrm{~N}_{2} \mathrm{~F}_{3}[\mathrm{M}-\mathrm{H}]^{-}$calculated $335.0649 \mathrm{~m} / \mathrm{z}$, found $335.0637 \mathrm{~m} / \mathrm{z}$ (Figure S32).

(2E)-N-[4-Nitro-3-(trifluoromethyl)phenyl]-3-phenylprop-2-enamide (18), Yield 60\%; Mp 181-183 ${ }^{\circ} \mathrm{C}$; IR $\left(\mathrm{cm}^{-1}\right): 3314,3086,1662,1620,1594,1544,1505,1424,1338,1319,1277,1247,1172,1112,1052,983$, 921, 901, 854, 840, 790, 760, 750, 709, 686, 645, 604, 593, 560, 505; ${ }^{1}$ H-NMR (DMSO- $d_{6}$ ), $\delta: 11.03$ (s, $1 \mathrm{H}), 8.38(\mathrm{~d}, J=2.1 \mathrm{~Hz}, 1 \mathrm{H}), 8.23(\mathrm{~d}, J=8.9 \mathrm{~Hz}, 1 \mathrm{H}), 8.13(\mathrm{dd}, J=8.9 \mathrm{~Hz}, J=2.1 \mathrm{~Hz}, 1 \mathrm{H}), 7.70(\mathrm{~d}$, $J=15.8 \mathrm{~Hz}, 1 \mathrm{H}), 7.67-7.66(\mathrm{~m}, 2 \mathrm{H}), 7.48-7.43(\mathrm{~m}, 3 \mathrm{H}), 6.81(\mathrm{~d}, J=15.8 \mathrm{~Hz}, 1 \mathrm{H}) ;{ }^{13} \mathrm{C}-\mathrm{NMR}\left(\right.$ DMSO- $\left.d_{6}\right), \delta$ : 164.54, 143.95, 142.27, 141.30, 134.23, 130.35, 129.10, 128.04, 127.84, $123.02(\mathrm{q}, J=33.2 \mathrm{~Hz}), 122.07(\mathrm{q}$, $J=273.1 \mathrm{~Hz}$ ), $120.94,117.32\left(\mathrm{q}, J=5.8 \mathrm{~Hz}\right.$ ) (Figure S33); HR-MS: $\mathrm{C}_{16} \mathrm{H}_{10} \mathrm{O}_{3} \mathrm{~N}_{2} \mathrm{~F}_{3}[\mathrm{M}-\mathrm{H}]^{-}$calculated $335.0649 \mathrm{~m} / \mathrm{z}$, found $335.0635 \mathrm{~m} / \mathrm{z}$ (Figure S34).

(2E)-N-[2,6-Dibromo-4-(trifluoromethyl)phenyl]-3-phenylprop-2-enamide (19), Yield 78\%; Mp 227-229 ${ }^{\circ} \mathrm{C}$; IR $\left(\mathrm{cm}^{-1}\right)$ : 3086, 2970, 2855, 1655, 1613, 1520, 1450, 1395, 1340, 1303, 1197, 1167, 1132, 1096, 1072, 1010, 984, 881, 862, 768, 743, 715, 692, 666, 566, 497; ${ }^{1} \mathrm{H}-\mathrm{NMR}$ (DMSO- $d_{6}$ ), $\delta: 10.36$ (s, 1H), 8.19 (s, 2H), 7.67-7.66 $(\mathrm{m}, 2 \mathrm{H}), 7.64(\mathrm{~d}, J=15.8 \mathrm{~Hz}, 1 \mathrm{H}), 7.47-7.42(3 \mathrm{H}), 6.90(\mathrm{~d}, J=15.8 \mathrm{~Hz}, 1 \mathrm{H}) ;{ }^{13} \mathrm{C}-\mathrm{NMR}\left(\mathrm{DMSO}-d_{6}\right), \delta$ : 163.42, 141.14, 140.13, 134.38, 130.08, 129.99 (q, J = 33.2 Hz), 129.16 (q, J = 4.3 Hz), 129.07, 127.88, 124.96, $122.29\left(\mathrm{q}, J=273.1 \mathrm{~Hz}\right.$ ), 120.45 (Figure S35); HR-MS: $\mathrm{C}_{16} \mathrm{H}_{9} \mathrm{ONBr}_{2} \mathrm{~F}_{3}[\mathrm{M}-\mathrm{H}]^{-}$calculated $445.9008 \mathrm{~m} / \mathrm{z}$, found $445.9002 \mathrm{~m} / \mathrm{z}$ (Figure S36).

(2E)-N-(2,6-Dibromo-3-chloro-4-fluorophenyl)-3-phenylprop-2-enamide (20), Yield: 74\%; Mp 234-235 ${ }^{\circ} \mathrm{C}$; IR $\left(\mathrm{cm}^{-1}\right): 3197,3001,1656,1664,1611,1571,1523,1442,1357,1339,1296,1285,1206,1179,1113,988$, 979, 854, 784, 763, 753, 723, 696, 684, 640, 581, 562, 530, 486, 442; ${ }^{1} \mathrm{H}-\mathrm{NMR}$ (DMSO- $d_{6}$ ), $\delta: 10.26$ (s, $1 \mathrm{H}), 8.07(\mathrm{~d}, J=8.9 \mathrm{~Hz}, 1 \mathrm{H}), 7.67-7.65(\mathrm{~m}, 2 \mathrm{H}), 7.62(\mathrm{~d}, J=15.8 \mathrm{~Hz}, 1 \mathrm{H}), 7.47-7.42(\mathrm{~m}, 3 \mathrm{H}), 6.87$ $(\mathrm{d}, J=15.8 \mathrm{~Hz}, 1 \mathrm{H}) ;{ }^{13} \mathrm{C}-\mathrm{NMR}\left(\mathrm{DMSO}-d_{6}\right), \delta: 163.64,156.15(\mathrm{~d}, J=252.9 \mathrm{~Hz}), 141.25,134.40,134.28$ $(\mathrm{d}, J=2.9 \mathrm{~Hz}), 130.04,129.07,127.85,126.30,122.82(\mathrm{~d}, J=10.1 \mathrm{~Hz}), 121.30(\mathrm{~d}, J=20.2 \mathrm{~Hz}), 120.52$, $119.79\left(\mathrm{~d}, J=24.6 \mathrm{~Hz}\right.$ ) (Figure S37); HR-MS: $\mathrm{C}_{15} \mathrm{H}_{8} \mathrm{ONBr}_{2} \mathrm{FCl}[\mathrm{M}-\mathrm{H}]^{-}$calculated $429.8651 \mathrm{~m} / \mathrm{z}$, found $429.8648 \mathrm{~m} / \mathrm{z}$ (Figure S38).

\subsection{Biological Testing}

\subsubsection{In Vitro Antibacterial Evaluation}

The synthesized compounds were evaluated for their in vitro antibacterial activity against representatives of multidrug-resistant bacteria, clinical isolates of methicillin-resistant Staphylococcus aureus (MRSA) 63718, and SA 630 that were obtained from the National Institute of Public Health (Prague, Czech Republic). S. aureus ATCC 29213 was used as the reference and quality control strain. Ampicillin (Sigma, St. Louis, MO, USA) was employed as the standard. All compounds and controls were prepared in triplicate. The screening was performed as described previously [26]. The results are summarized in Table 1. Antibacterial activity was assessed by determining MIC and MBC values. The broth microdilution method was applied. MIC values were determined in a microtiter plate. Aliquots from this plate were subcultivated on the Petri dish with Mueller-Hinton broth for the determination of MBC [43].

\subsubsection{In Vitro Antimycobacterial Evaluation}

The assessment of the in vitro antimycobacterial activity of the compounds was performed against Mycobacterium tuberculosis H37Ra/ATCC 25177 by means of the methodology described recently (e.g., [26]). Isoniazid (Sigma) was used as the standard. All compounds and controls were prepared in triplicate. The results are summarized in Table 1. 


\subsubsection{MTT Assay}

A compound was diluted in Mueller-Hinton broth to achieve the desired final concentrations of 0.5 and $1 \mu \mathrm{g} / \mathrm{mL}$, respectively. S. aureus ATCC 29213 bacterial suspension in sterile distilled water at $0.5 \mathrm{McF}$ arland was diluted 1:3. Inocula were added to each well by a multi-inoculator. Diluted bacteria in broth free from inhibiting compounds were used as the growth control. The procedure was performed three times. Plates were incubated at $37^{\circ} \mathrm{C}$ for $24 \mathrm{~h}$. After the incubation period, $10 \%$ well volume of MTT (3-(4,5-dimethylthiazol-2-yl)-2,5-diphenyltetrazolium bromide) reagent (Sigma) was mixed into each well and incubated at $37^{\circ} \mathrm{C}$ for $1 \mathrm{~h}$. Then $100 \mu \mathrm{L}$ of $17 \%$ sodium dodecyl sulphate in $40 \%$ dimethylformamide was added to each well. The plates were read at $570 \mathrm{~nm}$. The absorbance readings from the cells grown in the presence of the tested compounds were compared with uninhibited cell growth to determine relative percent inhibition. The percent inhibition was determined through the MTT assay. The percent viability is calculated through the comparison of a measured value and that of the uninhibited control: $\%$ viability $=\mathrm{OD}_{570 \mathrm{E}} / \mathrm{OD}_{570 \mathrm{P}} \times 100$, where $\mathrm{OD}_{570 \mathrm{E}}$ is the reading from the compound-exposed cells, while $\mathrm{OD}_{570 \mathrm{P}}$ is the reading from the uninhibited cells (positive control). Cytotoxic potential is determined by a percent viability of $<70 \%[43,59]$.

\subsubsection{In Vitro Cell Viability Assay}

The cytotoxic effect of the tested compounds was specified on THP1-Blue ${ }^{\mathrm{TM}} \mathrm{NF}-\mathrm{kB}$ cell line (Invivogen; San Diego, CA, USA), as described previously [28]. Briefly, cells resuspended in serum-free RPMI 1640 medium (Merck, Darmstadt, Germany) supplemented with antibiotics (100 U/mL penicillin and $100 \mathrm{mg} / \mathrm{mL}$ streptomycin (Merck)) and 10\% FBS (Merck) were seeded into 96-well plates (100 $\mu \mathrm{L} /$ well, i.e., 50,000 cells per each well). After $2 \mathrm{~h}$, tested compounds dissolved in DMSO $(1.25-20 \mu \mathrm{M})$ were added to the cells. The final concentration of DMSO was $0.1 \%(v / v)$ in each well. The viability analysis was performed after $24 \mathrm{~h}$ incubation with the tested substances using the WST-1 Cell Proliferation Reagent kit (Roche Diagnostics, Basel, Switzerland) according to the manufacturer's manual. The amount of formazan formed, which corresponded to the number of metabolically active cells in the culture, was calculated as a percentage of the control cells, which were treated only with serum-free RPMI 1640 medium and were assigned as $100 \%$. The $\mathrm{IC}_{50}$ values were calculated by four-parameter logistic (4PL) analysis from obtained viability curves by GraphPad Prism 8.0.1 (San Diego, CA, USA) software. The results are summarized in Table 1 as mean $\pm \operatorname{SEM}(n=6)$.

\subsubsection{Determination of NF-kB Activity}

To evaluate the anti-inflammatory potential of novel compounds, their ability to attenuate the lipopolysaccharide (LPS)-activated pro-inflammatory transcription nuclear factor (NF)- $\mathrm{kB}$ was measured as was described previously [28]. Briefly, THP1-Blue ${ }^{\mathrm{TM}}$ NF- $\mathrm{kB}$ cells were pretreated by tested compounds dissolved in DMSO in the non-toxic concentration $1 \mu \mathrm{M}$ for $1 \mathrm{~h}$. After LPS $(1 \mu \mathrm{g} / \mathrm{mL})$ stimulation, the NF- $\mathrm{kB}$ activity was evaluated by Quanti-Blue medium (Invivogen) according to the manufacturer's instructions. The results from 3 independent experiments performed in triplicate $(n=9)$ were analyzed by GraphPad Prism 8.0.1 software. The outlaying values were excluded by ROUT algorithms $(\mathrm{Q}=5 \%)$.

\subsection{Lipophilicity Determination by RP-HPLC (Capacity Factor $k /$ Calculated log $k$ )}

The HPLC separation system Merck Hitachi LaChrom Elite ${ }^{\circledR}$ equipped with a Merck Hitachi LaChrom Elite ${ }^{\circledR}$ L-2455 Diode-Array Detector (Hitachi High Technologies America, San Jose, CA, USA) was used. A chromatographic column Symmetry ${ }^{\circledR}$ C18 $5 \mu \mathrm{m}, 4.6 \times 250$ mm, Part No. W21751W016 (Waters Corp., Milford, MA, USA) was used. The HPLC separation process was monitored by the EZ CHROM Elite ${ }^{\circledR}$ software (Hitachi High Technologies America). The total flow of the column was $1.0 \mathrm{~mL} / \mathrm{min}$, injection $10 \mu \mathrm{L}$, column temperature $40^{\circ} \mathrm{C}$, and sample temperature $10^{\circ} \mathrm{C}$. The detection wavelength $214 \mathrm{~nm}$ was chosen. A KI methanolic solution was used for the dead time $\left(t_{\mathrm{D}}\right)$ determination. 
Retention times $\left(t_{\mathrm{R}}\right)$ were measured in minutes. Isocratic elution by a mixture of Metanol Chromasolv ${ }^{\mathrm{TM}}$ (Honeywell, St. Louis, MO, USA) (72\%) and $\mathrm{H}_{2} \mathrm{O}-\mathrm{HPLC}$ Mili-Q grade (Labconco, Kansas City, MO, USA) (28\%) as a mobile phase was used for the determination of capacity factor $k$, while isocratic elution by a mixture of Metanol Chromasolv ${ }^{\mathrm{TM}}$ (Honeywell) (72\%) and NaOAc buffer, $\mathrm{pH} 6.5$ and $7.4(28 \%)$ as a mobile phase were used for the determination of distribution coefficients $D_{6.5}$ and $D_{7.4}$. The capacity factors and distribution coefficients were calculated according to the formula $k(D)=\left(t_{\mathrm{R}}-t_{\mathrm{D}}\right) / t_{\mathrm{D}}$, where $t_{R}$ is the retention time of the solute and $t_{\mathrm{D}}$ is the dead time obtained using an unretained analyte. Each experiment was repeated three times. The calculated $\log k, \log D_{6.5}$, and $\log$ $D_{7.4}$ values of individual compounds are shown in Table 1.

\subsection{Lipophilicity Determination by RP-TLC}

$R_{M}$ values were determined from the RP-18 TLC measurements. The solutions of compounds in Metanol Chromasolv ${ }^{\mathrm{TM}}$ (Honeywell) were spotted on a RP-TLC plate (Silica gel Nano-SIL C18-100 UV $254,10 \times 10 \mathrm{~cm}$, Macherey-Nagel, Duren, Germany), $1.5 \mathrm{~cm}$ from the edge. The volatiles were carefully evaporated, and the plate was developed by $\mathrm{MeOH}(100 \%)$ or $\mathrm{MeOH}: \mathrm{H}_{2} \mathrm{O}-\mathrm{HPLC}(72: 28 v / v)$ or $\mathrm{MeOH}$ : NaOAc buffer, pH $7.4(72: 28 v / v)$. After drying, the spots were visualized under UV $(\lambda=365 \mathrm{~nm})$. $R_{M}$ data were obtained from equation: $R_{M}=\log \left(1 / R_{F}-1\right)$. Each experiment was repeated three times. The $R_{M}$ values of individual compounds are shown in Table 1 .

\subsection{Model Building and Experimental vs. Theoretical Lipophilicity Prediction}

CACTVS/csed and CORINA editors were engaged to produce each structural model and its initial spatial geometry. OpenBabel (inter)change file format converter was employed for data conversion. Sybyl-X 2.0/Certara software package running on a HP Z200 workstation with a Debian 10.0 operating system was used to conduct the molecular modeling simulations. The initial compound geometry optimization with MAXMIN2 module was performed using the standard Tripos force field (POWELL conjugate gradient algorithm) with a $0.01 \mathrm{kcal} / \mathrm{mol}$ energy gradient convergence criterion. The specification of the electrostatic potential values based on the partial atomic charges was carried out with the Gasteiger-Hückel method implemented in Sybyl-X.

An ensemble of freely/commercially available in silico predictors can be engaged to specify theoretically the numerical value of partition coefficients ( $\log P)$ as follows:

AlogPS-algorithm implemented by Tetko et al. [37] based on atom-type electrotopological-state (E-state) indices and neural networks (NN);

milogP - procedure proposed by Molinspiration for practical $\log \mathrm{P}$ calculations of almost all organic molecules as a sum of fragment-based contributions and correction factors;

$\mathrm{C} \log \mathrm{P}$ - fragment-based approach for estimation of lipophilicity based on structure-dependent correction values retrieved from Hansch and Leo's database that is implemented in Sybyl/ Centara software;

HyperChem $\log \mathrm{P}$ - an atom-additive method that estimates lipophilicity using the individual atomic contribution based on procedure proposed by Ghose, Prichett and Crippen;

MarvinSketch $\log \mathrm{P}$ - the overall lipophilicity of a molecule is composed of the contributing values of its atom types that were redefined to accommodate electron delocalization and contributions of ionic forms;

ChemSketch $\log \mathrm{P}$ - a comprehensive fragment-based algorithm with high quality models built using empirical data. Well-characterized $\log P$ contributions have been compiled for atoms; structural fragments and intramolecular interactions provided for more than $12 \times 10^{3}$ experimental $\log P$ values;

Dragon AlogP—statistical estimators of the Ghose-Crippen-Viswanadhan model were specified on the basis of known experimental $\log P$ for the training set of 8364 compounds. The overall approach of the lipophilic atomic-based constant is estimated with the contribution of 115 atom types; 
Dragon MlogP—the calculated partition coefficient includes VdW volume and Moriguchi polar parameters as correction factors. A regression MlogP model is based on 13 structural parameters that were rated on the training group of 1,230 organic molecules;

Kowwin-estimates the log octanol-water partition coefficient of chemicals using the atom/fragment contribution protocol;

XlogP3 - an atom-additive procedure with well-defined correction factors that engages an optimized atom typing approach calibrated on a big training set;

OSIRIS clogP-in house approach based on the cumulative sum of atom contributions calculated for more than 5000 compounds with experimentally measured $\log \mathrm{P}$ values as a training set. Predicting engine distinguishes 369 atom types;

ChemDraw $\log \mathrm{P}$ - the combination of Classic and GALAS algorithms for the prediction of partition coefficient based on a training set of $>11 \times 10^{3}$ compounds provides coverage for a broad chemical space;

Percepta clogP-based on $>12 \times 10^{3}$ of empirical $\log \mathrm{P}$ values with the algorithm that uses the principal of isolating carbons.

In order to detect the redundant descriptors in QSAR/QSPR studies, several methods of variable selection/elimination have been proposed, including the uninformative variable elimination (UVE-PLS), as well as its modifications, namely iterative variable elimination (IVE-PLS) [60]. Overall, the entire algorithm comprises of the following stages:

Stage 1. Standard PLS analysis with LOO-CV to evaluate the performance of the PLS model

Stage 2. Elimination of the matrix column with the lowest abs $(\operatorname{mean}(b) / \operatorname{std}(b))$ value

Stage 3. Standard PLS analysis of the new matrix without the column eliminated in Stage 2.

Stage 4. Iterative repetition of the Stages 1-3 to maximize the LOO $q_{c v}^{2}$.

\subsection{Similarity Assessment Using PCA and Tanimoto Coefficient}

The proper mapping of the molecular diversity in the theoretically infinite chemical space $\left(C S \approx 10^{60}-10^{200}\right)$ into the corresponding property space basically requires the multi-dimensional description of a molecule by a set of structural $(\mathrm{S})$ and physicochemical $(\mathrm{P})$ properties organized in a vector [61]. The molecular distribution of the experimental-based (FCS) and virtual-derived (VCS) compounds/models might be graphically displayed using the human friendly 2D/3D plots, e.g., in the procedure called Principal Component Analysis (PCA) [62]. PCA is a linear projection method designed to model multivariate data with a relatively small number of so-called principal components (scores and loadings) constructed in order to maximize the variance description of input data [63]. The PCA model with $f$ principal components for a data matrix $X$ can be presented as follows:

$$
X=T P^{T}+E
$$

where $X$ is a data matrix with $m$ objects and $n$ variables, $T$ is the score matrix with dimensions $(m \times f), P^{T}$ is a transposed matrix of loadings with dimensions $(f \times n)$ and $E$ is a matrix of the residual variance $(m \times n)$ that is not explained by the first $f$ principal components. Basically, the first few principal components often capture interesting information about the data structure and uncover groups of objects.

The structural relatedness between molecule library is usually estimated using a function mapping (dis)similarities between the pairs of bit-string descriptors given by the Tanimoto equation as follows:

$$
T(x, y)=\frac{n_{x y}}{\left(n_{x}+n_{y}-n_{x y}\right)}
$$

where $n_{x y}$ is the number of bits set into 1 shared in the fingerprint of molecules $x$ and $y, n_{x}$ is the number of bits set into 1 in molecule $x, n_{y}$ is the number of bits set into 1 in molecule $y$. Top-ranked objects are supposed to have similar properties, although the validity of this assumption is fairly 
questionable, because $70 \%$ of compounds with $T(x, y)>0.85$ to an active analog have comparatively low probability of being active in the same way [64].

\section{Conclusions}

A set of 20 cinnamic acid anilides (1 published recently and 19 newly synthesized) was investigated in relation to their biological activities and characterized by a series of experimental lipophilicity values generated using RP-HPLC and RP-TLC methods. All compounds were tested against the reference strain Staphylococcus aureus, two MRSA clinical isolates, and Mycobacterium tuberculosis. (2E)-N-[3-Fluoro-4-(trifluoromethyl)phenyl]-3-phenylprop-2-enamide (10) showed comparable or even better activity than the ampicillin. It was found that the activity of compound $\mathbf{1 0}$ is bactericidal. The screening of the cell viability performed using THP1-Blue ${ }^{\mathrm{TM}}$ NF- $\kappa \mathrm{B}$ cells demonstrated that only (2E)-N-(4-bromo-3-chlorophenyl)-3-phenylprop-2-enamide (11) showed significant cytotoxic effect. Moreover, all compounds were tested for their anti-inflammatory potential; (2E)-N-(2,6-dibromo-3-chloro-4-fluorophenyl)-3-phenylprop-2-enamide (20) attenuated the lipopolysaccharide-induced NF- $\mathrm{kB}$ activation and was more potent than the parental cinnamic acid. Unfortunately, the design of compound that combines both high antimicrobial activity and anti-inflammatory effect is a great challenge; compounds with preferential anilide ring substitution at the meta positions and optionally in combination with para show the highest antimicrobial activity, while the ortho position optionally in combination with meta are anti-inflammatory preferential. The similarity-related property space evaluation for the congeneric series of structural analogues was carried out using the principal component analysis (PCA). Moreover, the in silico approximation of the lipophilic values for the ensemble of anilides 1-20 was performed employing a set of free/commercial clogP estimators, subsequently corrected using the corresponding $\mathrm{pK}_{\mathrm{a}}$ calculated at physiological $\mathrm{pH}$ and subsequently cross-compared with the experimental parameter. The mean and median value of the selected estimators that averaged over the chosen $\log \mathrm{D}_{7.4}$ values were subsequently correlated with the experimental parameter with correlation coefficient of 0.65 , because not only the best inter-correlated $\operatorname{cog} \mathrm{D}_{7.4}$ values were specified in the consensus clogP approach. Finally, the similarity-driven investigation using Tanimoto metrics was conducted revealing the structural dissimilarities of nitro-substituted isomers (compounds $\mathbf{1 7}\left(\mathrm{R}=2-\mathrm{CF}_{3}-4-\mathrm{NO}_{2}\right)$ and $\mathbf{1 8}\left(\mathrm{R}=3-\mathrm{CF}_{3}-4-\mathrm{NO}_{2}\right)$ ) as compared with the remaining ones, which confirms our previous PCA findings. Interestingly, mono-bromo/chloro-substituted isomers (compounds $11(\mathrm{R}=3-\mathrm{Cl}-4-\mathrm{Br})$ and $12(\mathrm{R}=2-\mathrm{Br}-4-\mathrm{Cl})$ ) indicate the structural similarity to di-/tri-bromo/chloro-substituted positional isomers (molecules 4-9). Unfortunately, the similarity investigation did not provide valuable hints that could explain the noticeable variations in the toxic effect exerted by molecule $\mathbf{1 1}\left(\mathrm{IC}_{50}=6.5 \mu \mathrm{M}\right.$ on THP1-Blue ${ }^{\mathrm{TM}} \mathrm{NF}-\mathrm{KB}$ cells) and the remaining ones. In general, the distribution coefficient provides a more realistic estimation of lipophilicity in the relevant $\mathrm{pH}$ environments; therefore, $\log \mathrm{D}_{\mathrm{pH}}$ ought to be preferentially engaged in the QSPR study, especially for compounds that are likely to ionize in physiological media. Based on this study, the antiproliferative/antineoplastic activity of compound $\mathbf{1 1}$ will be investigated, while the rest of the tested compounds will be studied in relation to their antimicrobial and anti-inflammatory activities.

Supplementary Materials: The following are available online, Table S1: Theoretically estimated partition coefficient calculated by set of alternative methods for anilides 1-20. Table S2: Theoretically estimated $\mathrm{pK}_{\mathrm{a}}$ calculated by $\mathrm{ACD} /$ Percepta/pK $\mathrm{pK}_{\mathrm{a}}$ for anilides 1-20. Figure S1: ${ }^{13} \mathrm{C}-\mathrm{NMR}$ (DMSO- $d_{6}$ ) spectrum of (2E)-3-phenyl-N-(2,4,6-trifluorophenyl)prop-2-enamide (2). Figure S2: HR-MS record of (2E)-3-phenyl$N-\left(2,4,6\right.$-trifluorophenyl)prop-2-enamide (2). Figure S3: ${ }^{13} \mathrm{C}-\mathrm{NMR}$ (DMSO- $d_{6}$ ) spectrum of (2E)-3-phenyl$N$-(3,4,5-trifluorophenyl)prop-2-enamide (3). Figure S4: HR-MS record of (2E)-3-phenyl- $N$-(3,4,5-trifluorophenyl)prop-2-enamide (3). Figure S5: ${ }^{13} \mathrm{C}-\mathrm{NMR}\left(\mathrm{DMSO}-d_{6}\right)$ spectrum of $(2 E)-N-(2,4$-dichlorophenyl)-3-phenylprop2-enamide (4). Figure S6: HR-MS record of (2E)-N-(2,4-dichlorophenyl)-3-phenylprop-2-enamide (4). Figure S7: ${ }^{13} \mathrm{C}-\mathrm{NMR}$ (DMSO- $d_{6}$ ) spectrum of (2E)-3-phenyl-N-(2,4,5-trichlorophenyl)prop-2-enamide (5). Figure S8: HR-MS record of (2E)-3-phenyl- $N$-(2,4,5-trichlorophenyl)prop-2-enamide (5). Figure S9: ${ }^{13} \mathrm{C}-\mathrm{NMR}$ (DMSO- $d_{6}$ ) spectrum of (2E)-3-phenyl-N-(3,4,5-trichlorophenyl)prop-2-enamide (6). Figure S10: HR-MS record of (2E)-3-phenyl$N$-(3,4,5-trichlorophenyl)prop-2-enamide (6). Figure S11: ${ }^{13} \mathrm{C}-\mathrm{NMR}$ (DMSO- $\left.d_{6}\right)$ spectrum of (2E)-N-(2,4-dibromophenyl)-3-phenylprop-2-enamide (7). Figure S12: HR-MS record of (2E)-N-(2,4-dibromophenyl)-3-phenylprop- 
2-enamide (7). Figure S13: ${ }^{13} \mathrm{C}-\mathrm{NMR}$ (DMSO- $d_{6}$ ) spectrum of (2E)-N-(5-chloro-2-fluorophenyl)-3-phenylprop2-enamide (8). Figure S14: HR-MS record of (2E)-N-(5-chloro-2-fluorophenyl)-3-phenylprop-2-enamide (8). Figure S15: ${ }^{13} \mathrm{C}-\mathrm{NMR}$ (DMSO- $d_{6}$ ) spectrum of (2E)-N-(4-bromo-3-fluorophenyl)-3-phenylprop-2-enamide (9). Figure S16: HR-MS record of (2E)-N-(4-bromo-3-fluorophenyl)-3-phenylprop-2-enamide (9). Figure S17: ${ }^{13} \mathrm{C}-\mathrm{NMR}$ $\left(\mathrm{DMSO}-d_{6}\right)$ spectrum of (2E)- $N$-[3-fluoro-4-(trifluoromethyl)phenyl]-3-phenylprop-2-enamide (10). Figure S18: HR-MS record of (2E)-N-[3-fluoro-4-(trifluoromethyl)phenyl]-3-phenylprop-2-enamide (10). Figure S19: ${ }^{13} \mathrm{C}-\mathrm{NMR}$ (DMSO- $\left.d_{6}\right)$ spectrum of (2E)-N-(4-bromo-3-chlorophenyl)-3-phenylprop-2-enamide (11). Figure S20: HR-MS record of (2E)-N-(4-bromo-3-chlorophenyl)-3-phenylprop-2-enamide (11). Figure S21: ${ }^{13} \mathrm{C}-\mathrm{NMR}\left(\mathrm{DMSO}-d_{6}\right)$ spectrum of (2E)-N-(2-bromo-4-chlorophenyl)-3-phenylprop-2-enamide (12). Figure S22: HR-MS record of (2E)-N-(2-bromo-4-chlorophenyl)-3-phenylprop-2-enamide (12). Figure S23: ${ }^{13} \mathrm{C}$-NMR (DMSO- $\left.d_{6}\right)$ spectrum of (2E)- $N$-[2-bromo-5-(trifluoromethyl)phenyl]-3-phenylprop-2-enamide (13). Figure S24: HR-MS record of (2E)-N-[2-bromo-5-(trifluoromethyl)phenyl]-3-phenylprop-2-enamide (13). Figure S25: ${ }^{13} \mathrm{C}-\mathrm{NMR}\left(\mathrm{DMSO}-d_{6}\right)$ spectrum of (2E)-N-[4-fluoro-2-(trifluoromethyl)phenyl]-3-phenylprop-2-enamide (14). Figure S26: HR-MS record of (2E)-N-[4-fluoro-2-(trifluoromethyl)phenyl]-3-phenylprop-2-enamide (14). Figure S27: ${ }^{13} \mathrm{C}-\mathrm{NMR}\left(\mathrm{DMSO}-d_{6}\right)$ spectrum of (2E)- $N$-[4-chloro-2-(trifluoromethyl)phenyl]-3-phenylprop-2-enamide (15). Figure S28: HR-MS record of (2E)- $N$-[4-chloro-2-(trifluoromethyl)phenyl]-3-phenylprop-2-enamide (15). Figure S29: ${ }^{13} \mathrm{C}-\mathrm{NMR}\left(\mathrm{DMSO}-d_{6}\right)$ spectrum of (2E)-N-[4-bromo-2-(trifluoromethyl)phenyl]-3-phenylprop-2-enamide (16). Figure S30: HR-MS record of (2E)-N-[4-bromo-2-(trifluoromethyl)phenyl]-3-phenylprop-2-enamide (16). Figure S31: ${ }^{13} \mathrm{C}-\mathrm{NMR}\left(\mathrm{DMSO}-d_{6}\right)$ spectrum of (2E)-N-[4-nitro-2-(trifluoromethyl)phenyl]-3-phenylprop-2-enamide (17). Figure S32: HR-MS record of (2E)-N-[4-nitro-2-(trifluoromethyl)phenyl]-3-phenylprop-2-enamide (17). Figure S33: ${ }^{13} \mathrm{C}-\mathrm{NMR}\left(\mathrm{DMSO}-d_{6}\right)$ spectrum of (2E)-N-[4-nitro-3-(trifluoromethyl)phenyl]-3-phenylprop-2-enamide (18). Figure S34: HR-MS record of (2E)-N-[4-nitro-3-(trifluoromethyl)phenyl]-3-phenylprop-2-enamide (18). Figure S35: ${ }^{13} \mathrm{C}-\mathrm{NMR}$ (DMSO- $d_{6}$ ) spectrum of (2E)-N-[2,6-dibromo-4-(trifluoromethyl)phenyl]-3-phenylprop-2-enamide (19). Figure S36: HR-MS record of (2E)-N-[2,6-dibromo-4-(trifluoromethyl)phenyl]-3-phenylprop-2-enamide (19). Figure S37: ${ }^{13} \mathrm{C}-\mathrm{NMR}$ (DMSO- $d_{6}$ ) spectrum of (2E)-N-(2,6-dibromo-3-chloro-4-fluorophenyl)-3-phenylprop-2-enamide (20). Figure S38: HR-MS record of (2E)- $N$-(2,6-dibromo-3-chloro-4-fluorophenyl)-3-phenylprop-2-enamide (20).

Author Contributions: J.K., T.S. and F.D. synthesized the compounds. M.O., T.J., M.H. analyzed the compounds. H.M. and J.H. performed biological screening. J.J. designed the compounds. A.B., V.K., A.S. (Adam Smolinski) and A.S. (Aleksandra Swietlicka) performed theoretical lipophilicity calculations, PCA, IVE-PLS. A.B. and J.J. wrote the paper. All authors have read and agreed to the published version of the manuscript.

Funding: This study was supported by the Slovak Research and Development Agency (APVV-17-0373) and by Palacky University Olomouc (IGA_PrF_2020_023). Knowledge gained within project APVV-0516-12 has been used in the results. M.O. was supported by SustES (CZ.02.1.01/0.0/0.0/16_019/0000797).

Acknowledgments: We would like to acknowledge the OpenEye and OpenBabel Scientific Software for providing free academic licenses.

Conflicts of Interest: The authors declare no conflict of interest.

\section{References}

1. Medzhitov, R. Origin and physiological roles of inflammation. Nature 2008, 454, 428-435. [CrossRef]

2. Oehling, A.K. Bacterial infection as an important triggering factor in bronchial asthma. J. Investig. Allergol. Clin. Immunol. 1999, 9, 6-13.

3. Sreenivasan, P.K.; Gaffar, A. Antibacterials as anti-inflammatory agents: Dual action agents for oral health. Antonie Van Leeuwenhoek 2008, 93, 227-239. [CrossRef] [PubMed]

4. Qiu, C.C.; Caricchio, R.; Gallucci, S. Triggers of autoimmunity: The role of bacterial infections in the extracellular exposure of lupus nuclear autoantigens. Front. Immunol. 2019, 10, 2608. [CrossRef] [PubMed]

5. Van Elsland, D.; Neefjes, J. Bacterial infections and cancer. EMBO Rep. 2018, 19, e46632. [CrossRef]

6. Chen, L.; Deng, H.; Cui, H.; Fang, J.; Zuo, Z.; Deng, J.; Li, Y.; Wang, X.; Zhao, L. Inflammatory responses and inflammation-associated diseases in organs. Oncotarget 2017, 9, 7204-7218. [CrossRef] [PubMed]

7. Vasaikar, S.; Bhatia, P.; Bhatia, P.G.; Yaiw, K.C. Complementary approaches to existing target based drug discovery for identifying novel drug targets. Biomedicines 2016, 4, 27. [CrossRef] [PubMed]

8. Ul Islam, N.; Amin, R.; Shahid, M.; Amin, M.; Zaib, S.; Iqbal, J. A multi-target therapeutic potential of Prunus domestica gum stabilized nanoparticles exhibited prospective anticancer, antibacterial, urease-inhibition, anti-inflammatory and analgesic properties. BMC Complement. Altern. Med. 2017, 17, 276. [CrossRef]

9. Brullo, C.; Massa, M.; Rapetti, F.; Alfei, S.; Bertolotto, M.B.; Montecucco, F.; Signorello, M.G.; Bruno, O. New hybrid pyrazole and imidazopyrazole antinflammatory agents able to reduce ROS production in different biological targets. Molecules 2020, 25, 899. [CrossRef] 
10. Ramsay, R.R.; Popovic-Nikolic, M.R.; Nikolic, K.; Uliassi, E.; Bolognesi, M.L. A perspective on multi-target drug discovery and design for complex diseases. Clin. Transl. Med. 2018, 7, 3. [CrossRef]

11. Bolognesi, M.L. Polypharmacology in a single drug: Multitarget drugs. Curr. Med. Chem. 2013, 20, 1639-1645. [CrossRef] [PubMed]

12. Talevi, A. Multi-target pharmacology: Possibilities and limitations of the "skeleton key approach" from a medicinal chemist perspective. Front. Pharmacol. 2015, 6, 205. [CrossRef] [PubMed]

13. Bräse, S. Privileged Scaffolds in Medicinal Chemistry: Design, Synthesis, Evaluation; Royal Society of Chemistry: Cambridge, UK, 2016.

14. Gaikwad, N.; Nanduri, S.; Madhavi, Y.V. Cinnamamide: An insight into the pharmacological advances and structure-activity relationships. Eur. J. Med. Chem. 2019, 181, 111561. [CrossRef] [PubMed]

15. Das, A.B.; Goud, V.V.; Das, C. Phenolic compounds as functional ingredients in beverages. In Value-Added Ingredients and Enrichments of Beverages; Grumezescu, A.M., Holban, A.M., Eds.; Woodhead Publishing: Duxford, UK; Elsevier: Duxford, UK, 2019; pp. 285-323.

16. Sharma, P. Cinnamic acid derivatives: A new chapter of various pharmacological activities. J. Chem. Pharm. Res. 2011, 3, 403-423.

17. Peperidou, A.; Kapoukranidou, D.; Kontogiorgis, C.; Hadjipavlou-Litina, D. Multitarget molecular hybrids of cinnamic acids. Molecules 2014, 19, 20197-20226. [CrossRef]

18. Peperidou, A.; Pontiki, E.; Hadjipavlou-Litina, D.; Voulgari, E.; Avgoustakis, K. Multifunctional cinnamic acid derivatives. Molecules 2017, 22, 1247. [CrossRef]

19. Guzman, J.D. Natural cinnamic acids, synthetic derivatives and hybrids with antimicrobial activity. Molecules 2014, 19, 19292-19349. [CrossRef]

20. Lima, T.C.; Ferreira, A.R.; Silva, D.F.; Lima, E.O.; de Sousa, D.P. Antifungal activity of cinnamic acid and benzoic acid esters against Candida albicans strains. Nat. Prod. Res. 2018, 32, 572-575. [CrossRef]

21. Dolab, J.G.; Lima, B.; Spaczynska, E.; Kos, J.; Cano, N.H.; Feresin, G.; Tapia, A.; Garibotto, F.; Petenatti, E.; Olivella, M.; et al. Antimicrobial activity of Annona emarginata (Schltdl.) H. Rainer and most active isolated compound against clinically important bacteria. Molecules 2018, 23, 1187. [CrossRef]

22. Pontiki, E.; Peperidou, A.; Fotopoulos, I.; Hadjipavlou-Litina, D. Cinnamate hybrids: A unique family of compounds with multiple biological activities. Curr. Pharm. Biotechnol. 2018, 19, 1019-1048. [CrossRef]

23. Silva, A.T.; Bento, C.M.; Pena, A.C.; Figueiredo, L.M.; Prudencio, C.; Aguiar, L.; Silva, T.; Ferraz, R.; Gomes, M.S.; Teixeira, C.; et al. Cinnamic acid conjugates in the rescuing and repurposing of classical antimalarial drugs. Molecules 2019, 25, 66. [CrossRef]

24. Martinez, M.D.; Riva, D.A.; Garcia, C.; Duran, F.J.; Burton, G. Synthesis and antibacterial activity of difluoromethyl cinnamoyl amides. Molecules 2020, 25, 789. [CrossRef] [PubMed]

25. Fungicide Resistance Action Committee. FRAC Code ListC 2020: Fungal Control Agents Sorted by Cross Resistance Pattern and Mode of Action; Fungicide Resistance Action Committee, Croplife International: Brussels, Belgium, 2020.

26. Pospisilova, S.; Kos, J.; Michnova, H.; Kapustikova, I.; Strharsky, T.; Oravec, M.; Moricz, A.M.; Bakonyi, J.; Kauerova, T.; Kollar, P.; et al. Synthesis and spectrum of biological activities of novel $N$-arylcinnamamides. Int. J. Mol. Sci. 2018, 19, 2318. [CrossRef] [PubMed]

27. Pospisilova, S.; Kos, J.; Michnova, H.; Strharsky, T.; Cizek, A.; Jampilek, J. N-Arylcinnamamides as Antistaphylococcal Agents. In Proceedings of the 4th International Electronic Conference on Medicinal Chemistry, ECMC-4, 1-30 November 2018; p. 5576. Available online: https:/sciforum.net/manuscripts/5576/ slides.pdf (accessed on 4 August 2020).

28. Hosek, J.; Kos, J.; Strharsky, T.; Cerna, L.; Starha, P.; Vanco, J.; Travnicek, Z.; Devinsky, F.; Jampilek, J. Investigation of anti-inflammatory potential of n-arylcinnamamide derivatives. Molecules 2019, $24,4531$. [CrossRef] [PubMed]

29. Veber, D.F.; Johnson, S.R.; Cheng, H.Y.; Smith, B.R.; Ward, K.W.; Kopple, K.D. Molecular properties that influence the oral bioavailability of drug candidates. J. Med. Chem. 2002, 45, 2615-2623. [CrossRef] [PubMed]

30. Van de Waterbeemd, H.; Gifford, E. ADMET in silico modeling: Towads prediction paradise? Nat. Rev. Drug Discov. 2003, 2, 192-204. [CrossRef] [PubMed]

31. Fukunishi, Y.; Nakamura, H. Definition of drug-likeness for compound affinity. J. Chem. Inf. Model. 2011, 51, 1012-1016. [CrossRef] 
32. Lipinski, C.A.; Lombardo, F.; Dominy, B.W.; Feeney, P.J. Experimental and computational approaches to estimate solubility and permeability in drug discovery and development settings. Adv. Drug Deliv. Rev. 2001, 46, 3-26. [CrossRef]

33. Bak, A.; Kozik, V.; Smolinski, A.; Jampilek, J. In silico estimation of basic activity-relevant parameters for a set of drug absorption promoters. SAR QSAR Environ. Res. 2017, 28, 427-449. [CrossRef]

34. Arnott, J.A.; Planey, S.L. The influence of lipophilicity in drug discovery and design. Expert Opin. Drug Discov. 2012, 7, 863-875. [CrossRef]

35. Efremov, R.G.; Chugunov, A.O.; Pyrkov, T.V.; Priestle, J.P.; Arseniev, A.S.; Jacoby, E. Molecular lipophilicity in protein modeling and drug design. Curr. Med. Chem. 2007, 14, 393-415. [CrossRef] [PubMed]

36. Mannhold, R.; Poda, G.I.; Ostermann, C.; Tetko, I.V. Calculation of molecular lipophilicity: State-of-the-art and comparison of logP methods on more than 96,000 compounds. J. Pharm. Sci. 2009, 3, 861-864. [CrossRef] [PubMed]

37. Tetko, I.; Poda, G.I. Application of ALOGPS 2.1 to predict $\log \mathrm{D}$ distribution coefficient for Pfizer proprietary compounds. J. Med. Chem. 2004, 47, 5601-5604. [PubMed]

38. Lipinski, C.A. Lead- and drug-like compounds: The rule-of-five revolution. Drug Discov. Today Technol. 2004, 1, 337-341. [CrossRef] [PubMed]

39. Kah, M.; Brown, C.D. LogD: Lipophilicity for ionisable compounds. Chemosphere 2008, 72, 1401-1408. [CrossRef] [PubMed]

40. Bhal, S.K.; Kassam, K.; Peirson, I.G.; Pearl, G.M. The rule of five revisited: Applying $\log D$ in place of $\log P$ in drug-likeness filters. Mol. Pharm. 2007, 40, 556-560. [CrossRef]

41. Xing, L.; Glen, C. Novel methods for the predicition of $\log \mathrm{P}, \mathrm{pKa}$ and $\log$ D. J. Chem. Inf. Comput. Sci. 2002, 42, 796-805. [CrossRef]

42. Rupp, M.; Körner, R.; Tetko, I.V. Predicting the pKa of small molecules. Comb. Chem. High Throughput Screen. 2011, 14, 307-327. [CrossRef]

43. Zadrazilova, I.; Pospisilova, S.; Masarikova, M.; Imramovsky, A.; Ferriz, J.M.; Vinsova, J.; Cizek, A.; Jampilek, J. Salicylanilide carbamates: Promising antibacterial agents with high in vitro activity against methicillin-resistant Staphylococcus aureus (MRSA). Eur. J. Pharm. Sci. 2015, 77, 197-207. [CrossRef]

44. International Organization for Standardization. ISO 10993-5:2009 Biological Evaluation of Medical Devices Part 5: Tests for In Vitro Cytotoxicity; International Organization for Standardization: Geneva, Switzerland, 2009; last revision 2017.

45. Grela, E.; Kozłowska, J.; Grabowiecka, A. Current methodology of MTT assay in bacteria-A review. Acta Histochem. 2018, 120, 303-311. [CrossRef]

46. Bender, A.; Scheiber, J.; Jenkins, J.L.; Sukuru, S.C. How similar are similarity searching methods? A principal component analysis of molecular descriptor space. J. Chem. Inf. Model. 2009, 49, 108-119. [CrossRef]

47. Fialkowski, M.; Bishop, K.J.M.; Chubukov, V.A.; Campbell, C.J.; Grzybowski, B.A. Architecture and evolution of organic chemistry. Angew. Chem. Int. Ed. 2005, 44, 7263-7269. [CrossRef] [PubMed]

48. Bak, A.; Pizova, H.; Kozik, V.; Vorcakova, K.; Kos, J.; Treml, J.; Odehnalova, K.; Oravec, M.; Imramovsky, A.; Bobal, P.; et al. SAR-mediated similarity assessment of the property profile for new, silicon-based AChE/BChE inhibitors. Int. J. Mol. Sci. 2019, 20, 5385. [CrossRef] [PubMed]

49. Bak, A.; Kozik, V.; Malik, I.; Jampilek, J.; Smolinski, A. Probability-driven 3D pharmacophore mapping of antimycobacterial potential of hybrid molecules combining phenylcarbamoyloxy and $\mathrm{N}$-arylpiperazine fragments. SAR QSAR Environ. Res. 2018, 29, 801-821. [CrossRef]

50. Pizova, H.; Havelkova, M.; Stepankova, S.; Bak, A.; Kauerova, T.; Kozik, V.; Oravec, M.; Imramovsky, A.; Kollar, P.; Bobal, P.; et al. Proline-based carbamates as cholinesterase inhibitors. Molecules 2017, 22, 1969. [CrossRef]

51. Martel, S.; Gillerat, F.; Carosati, E.; Maiarelli, D.; Tetko, I.V.; Mannhold, R.; Carrupt, P.A. Large, chemically diverse dataset of $\log$ P measurements for benchmarking studies. Eur. J. Pharm. Sci. 2013, 48, 21-29. [CrossRef] [PubMed]

52. Tetko, I.V. Computing chemistry on the web. Drug Discov. Today 2005, 10, 1497-1500. [CrossRef]

53. Peltason, L.; Bajorath, J. Systematic computational analysis of structure-activity relationships: Concepts, challenges and recent advances. Future Med. Chem. 2009, 1, 451-466. [CrossRef]

54. Maggiora, G.M.; Shanmugasundaram, V. Molecular similarity measures. Methods Mol. Biol. 2011, 672, 39-100. [PubMed] 
55. Holliday, J.D.; Salim, N.; Whittle, M.; Willett, P. Analysis and display of the size dependence of chemical similarity coefficients. J. Chem. Inf. Comput. Sci. 2003, 43, 819-828. [CrossRef] [PubMed]

56. Rozas, I.; Du, Q.; Arteca, G.A. Interrelation between electrostatic and lipophilicity potentials on molecular surfaces. J. Mol. Graph. 1995, 13, 98-108. [CrossRef]

57. Zupan, J.; Gasteiger, J. Neural Networks and Drug Design for Chemists, 2nd ed.; Wiley-VCH: Weinheim, Germany, 1999.

58. Bak, A.; Wyszomirski, M.; Magdziarz, T.; Smolinski, A.; Polanski, J. Structure-based modeling of dye-fiber affinity with SOM-4D-QSAR paradigm: Application to set of anthraquinone derivatives. Comb. Chem. High Throughput Screen. 2014, 17, 485-502. [CrossRef]

59. Michnova, H.; Pospisilova, S.; Gonec, T.; Kapustikova, I.; Kollar, P.; Kozik, V.; Musiol, R.; Jendrzejewska, I.; Vanco, J.; Travnicek, Z.; et al. Bioactivity of methoxylated and methylated 1-hydroxynaphthalene-2carboxanilides: Comparative molecular surface analysis. Molecules 2019, 24, 2991. [CrossRef] [PubMed]

60. Bak, A.; Polanski, J. Modeling robust QSAR 3: SOM-4D-QSAR with iterative variable elimination IVE-PLS: Application to steroid, azo dye, and benzoic acid series. J. Chem. Inf. Model. 2007, 47, 1469-1480. [CrossRef] [PubMed]

61. Polanski, J.; Bak, A.; Gieleciak, R.; Magdziarz, T. Modeling robust QSAR. J. Chem. Inf. Model. 2003, 46, 2310-2318. [CrossRef] [PubMed]

62. Bak, A.; Kozik, V.; Smolinski, A.; Jampilek, J. Multidimensional (3D/4D-QSAR) probability-guided pharmacophore mapping: Investigation of activity profile for a series of drug absorption promoters. RSC Adv. 2016, 6, 76183-76205. [CrossRef]

63. Bak, A.; Kozik, V.; Kozakiewicz, D.; Gajcy, K.; Strub, D.J.; Swietlicka, A.; Stepankova, S.; Imramovsky, A.; Polanski, J.; Smolinski, A.; et al. Novel benzene-based carbamates for AChE/BChE inhibition: Synthesis and ligand/structure-oriented SAR study. Int. J. Mol. Sci. 2019, 20, 1524. [CrossRef]

64. Xie, X.Q.; Chen, J.Z. Data mining a small molecule drug screening representative subset from NIH PubChem. J. Chem. Inf. Model. 2008, 48, 465-475. [CrossRef]

Sample Availability: Samples of the compounds are available from the authors.

(C) 2020 by the authors. Licensee MDPI, Basel, Switzerland. This article is an open access article distributed under the terms and conditions of the Creative Commons Attribution (CC BY) license (http://creativecommons.org/licenses/by/4.0/). 